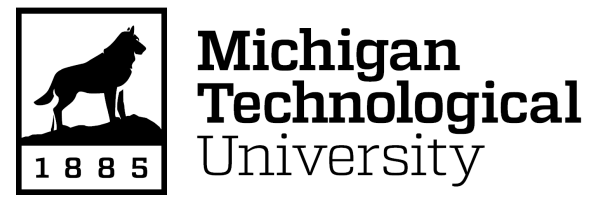

Michigan Technological University Digital Commons @ Michigan Tech

Dissertations, Master's Theses and Master's Reports

2017

\title{
TRADITIONAL MEDICINE USE IN CHAMORRO CUÉ, GRAL. E. AQUINO, SAN PEDRO, PARAGUAY
}

Noah Goyke

Michigan Technological University, ngoyke@mtu.edu

Copyright 2017 Noah Goyke

\section{Recommended Citation}

Goyke, Noah, "TRADITIONAL MEDICINE USE IN CHAMORRO CUÉ, GRAL. E. AQUINO, SAN PEDRO, PARAGUAY", Open Access Master's Thesis, Michigan Technological University, 2017.

https://doi.org/10.37099/mtu.dc.etdr/337

Follow this and additional works at: https://digitalcommons.mtu.edu/etdr

Part of the Biological and Physical Anthropology Commons 
TRADITIONAL MEDICINE USE IN CHAMORRO CUÉ, GRAL. E. AQUINO, SAN PEDRO, PARAGUAY

By

Noah A. Goyke

A THESIS

Submitted in partial fulfillment of the requirements for the degree of

MASTER OF SCIENCE

In Forestry

MICHIGAN TECHNOLOGICAL UNIVERSITY

2017

(c) 2017 Noah A. Goyke 
This thesis has been approved in partial fulfillment of the requirements for the Degree of MASTER OF SCIENCE in Forestry.

School of Forest Resources and Environmental Science

Thesis Advisor: $\quad$ Dr. Blair Orr

Committee Member: $\quad$ Dr. Joseph Bump

Committee Member: $\quad$ Dr. Chelsea Schelly

School Dean: Dr. Terry Sharik 
To Zully and Silas 


\section{Table of Contents}

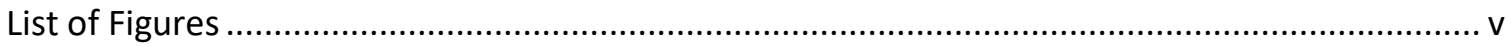

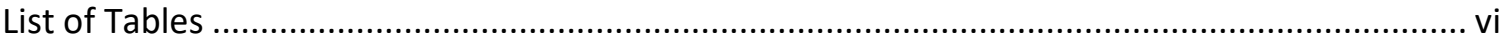

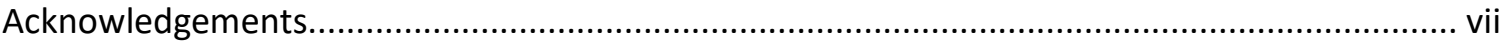

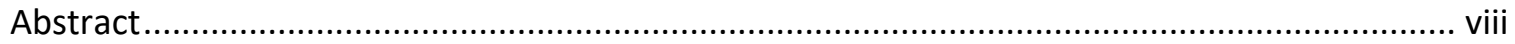

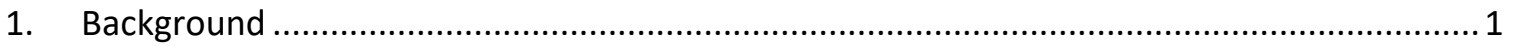

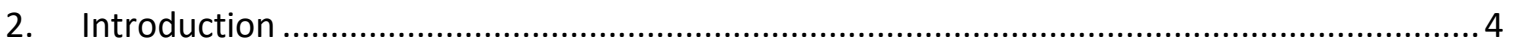

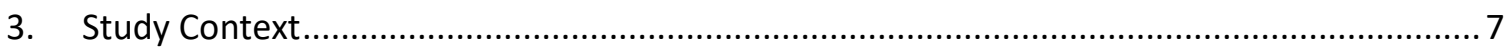

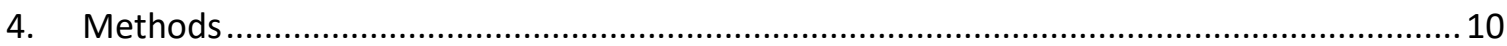

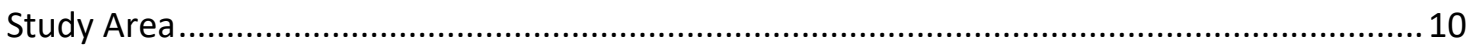

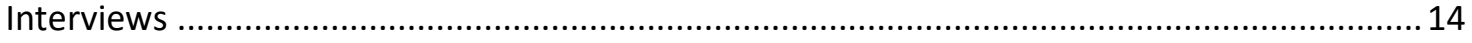

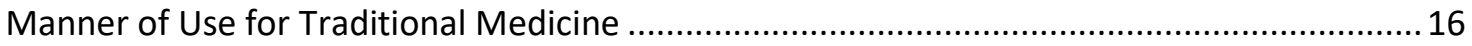

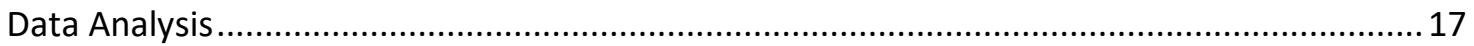

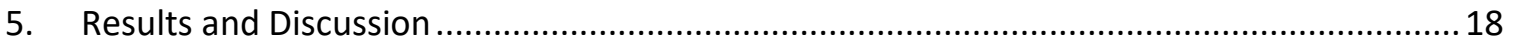

Presence of Ailments by Season and Place of Residence ....................................................... 18

Use of Pharmaceutical and Traditional Medicine by Season and Place of Residence...............20

Source of Medicinal Plants by Season and Place of Residence ................................................ 21

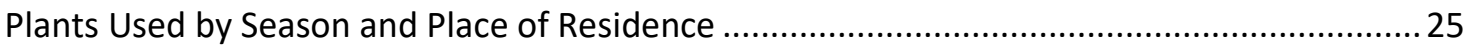

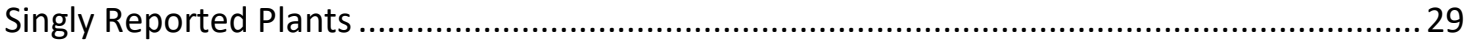

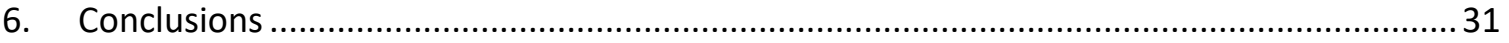

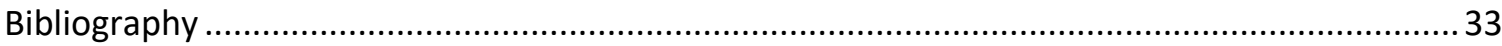

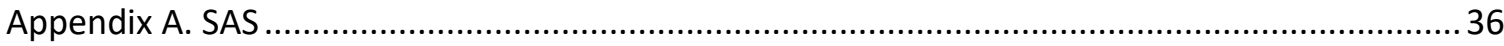

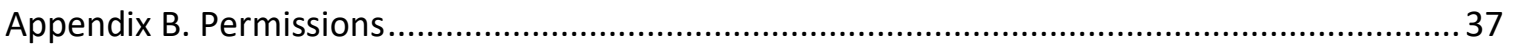

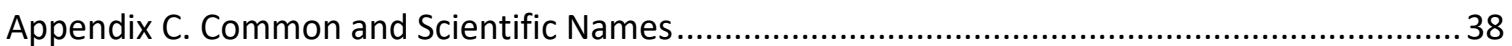




\section{List of Figures}

Figure 1.1. The Author drinking terere with a co-worker at the elementary school. Photo Credit Matthew Meglan

Figure 1.2. The traditonal guampa and mbombilla used for drinking terere and mate. Photo

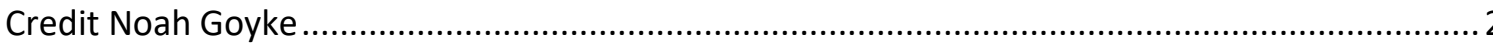

Figure 1.3. The Author's home in Chamorro Cue. Photo Credit Matthew Meglan .......................... 3

Figure 3.1. Ecoregions of Paraguay (map created by Noah Goyke, data from SEAM) ...................9

Figure 4.1. Paraguay in relation to South America (d-maps.com) .............................................. 10

Figure 4.2. Department of Sand Pedro in relation to Paraguay (d-maps.com) ........................... 11

Figure 4.3. Growth of Gral. E. Aquino from the years 2002 to 2015. (Google Earth)...................12

Figure 5.1. Distribution of the 18 plants with the highest (RI) by $(R)$ and $(A)$ values..................26

Figure 5.2. Distribution of the 18 plants with the highest (RI) by Winter (RI) and Summer (RI) values, and series defined by greater Summer (RI) or Winter (RI) values. 26 


\section{List of Tables}

Table 4.1. Average Family Size and Generations per Family by rural and urban place of residence (average and confidence interval) . .15

Table 5.1. Ailment presence by season and place of residence (as a percent of all participants) 18

Table 5.2. Medicine type used by place of residence (as a percent of all participants) ............... 20

Table 5.3. Natural remedy source by season (as a percent of all responses) ..............................22

Table 5.4. Natural remedy source by place of residence (as a percent of all responses) .............24

Table 5.5. Relative importance of eighteen most important plants, with $(A)$ and $(R)$ values and (RI) values for summer and winter.

25

Table 5.6. Number of singly reported responses by season and place of residence. 29

Table 5.7. Relative importance of seven most important plants reported as being used to treat one ailment per season

Table C.1. Common and Scientific Names of Medicinal Plants, organized by family. 


\section{Acknowledgements}

Throughout the process of this project, from idea to product, I have had help from a large number of individuals whom I would like to take the time to thank.

Thank you to my graduate advisor Dr. Blair Orr for patience, guidance, and for being my enemy when I needed to fight to make my thesis better and for being my friend when I needed to see that it was not a disaster.

Agradezco mucho a la comunidad de Chamorro Cué en general y específicamente a las cuarenta y cuatro familias quienes participaron en mis encuestas. Especialmente quiero agradecer la familia de Martin González y Don Lucrecio Santa Cruz por ser mis familias anfitrionas por varios meses mientras no pude hablar tanto. Gracias a Director Ramón y toda la gente de Esc. Bás. N 1883 por sus paciencia y apoyo. Unas gracias especiales a la familia de Blas Reinoso por enseñarme tomar terere y a Samuel e Hilvania, por ser mis vecinos, mis padres, mis amigos y mis guíos por dos años.

Thank you to Peace Corps Paraguay, for approving my project. In particular, thank you Elizabeth Cabrera and Alistair Kerlin for support, help tracking down resources, and finding a balance between work, study and life.

Thank you to friends and family back home - Mom and Dad, Matt for coming down to visit, Ben for being so interested in terere, Joe for drinking mate with me.

Un final gracias a Zully. Por apoyarme siempre. Por ayudarme y por ser parte de mi vida. Gracias a ti y a Gael por ser la mejor familia que pude imaginar. Aguije, rojayhu terei. 


\section{Abstract}

Rural Paraguay presents great opportunities for investigation into the subtle differences in the use of medicinal plants across seasons and the urban versus rural dichotomy in a rapidly globalizing society. One of the most interesting opportunities is comparing a rural population to the population of an urban center that has be the destination of local migration from the rural communities surveyed. This study investigates the seasonal differences and difference between urban and rural residents in the type of medication used to treat thirteen different common ailments and the source of medicinal plants used to treat those ailments. Interviews performed in January through March 2015 and repeated in June through August 2015 revealed small differences seasonally and between places of residence but a larger homogeneity in the two populations, a homogeneity that stems from the recent micro-migration of urban residents from nearby rural communities. 


\section{Background}

During the three years I spent in Paraguay I had the opportunity to observe and to participate in the ritual of traditional medicine in a way that many students conducting master's research are unable (Figure 1.1). What I observed was unlike the charismatic rituals described in ethnobiological literature (Arenas 1987, Schmeda-Hirschmann, 1993). Instead, I was blessed to observe the complex ritual of daily life in a single community, and equally complex role that traditional medicine plays in the community. I was able to witness a subdued coming of age ritual play out over months before my eyes; the movement from outside to inside the tea drinking circle and the symbolic entrance into maturity that comes with it. I was able to experience firsthand the benefits of traditional knowledge to human health and see how that same knowledge is being transferred from one generation to another in a globalizing world.

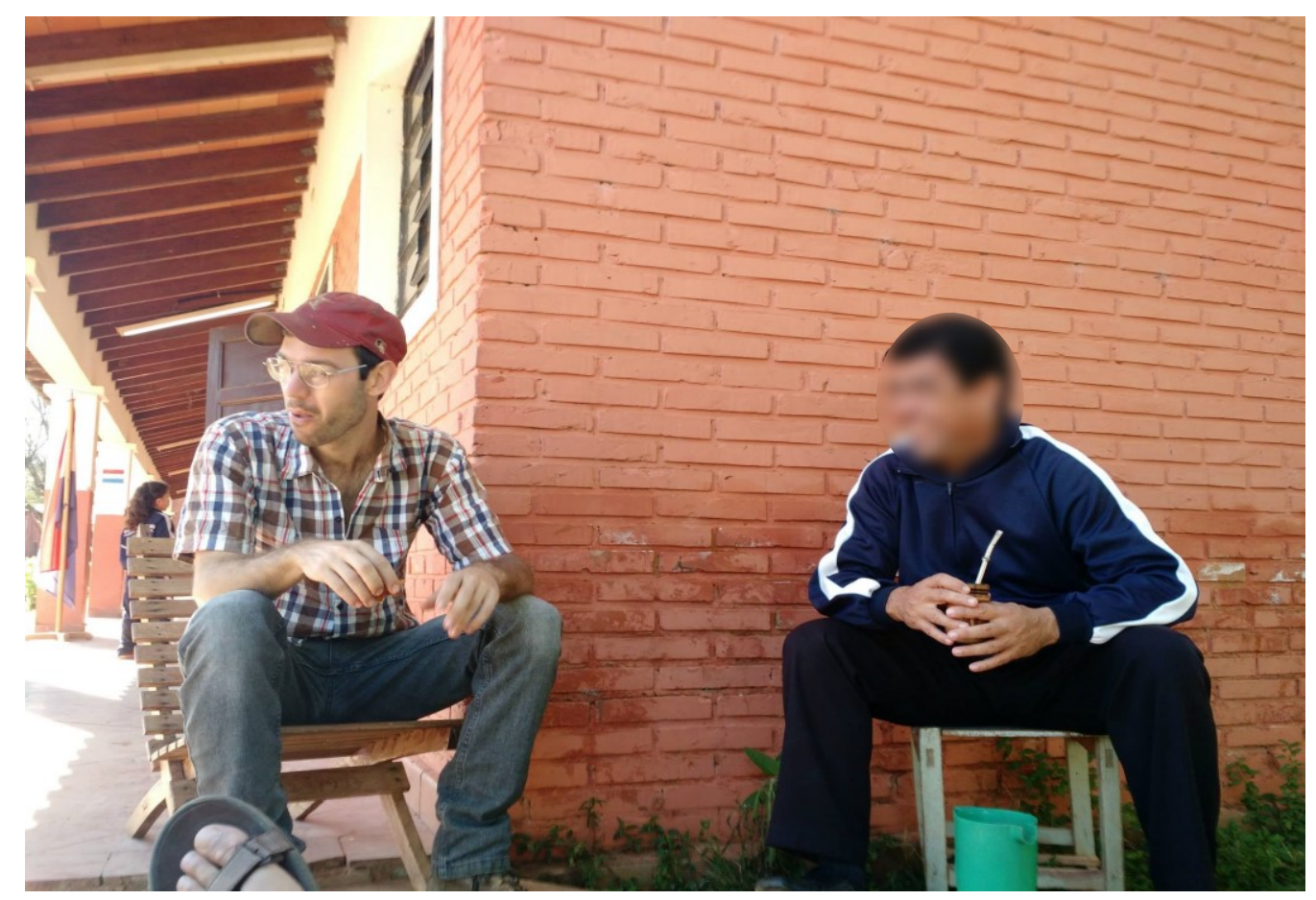

Figure 1.1. The Author drinking terere with a co-worker at the elementary school. Photo Credit Matthew Meglan 
This study comes directly from my observations of and experiences with traditional medicine. In the role of extensionsist I had reason to, or excuse for, visiting nearly all of the homes in the small community of Chamorro Cué, many of them as often as once a week or more. Through those connections I formed a network of relationships with families in the neighboring urban area as well, friends and relatives of my own friends and neighbors. Each visit, be it personal or professional, included some variation of the following at its start - "Mba'eichapa, ja'u la terere" followed by the response "Ja'u". "Hola, no te gusta terere" - "Hello, do you want some terere" serving as the invitation to make time for small talk, always accompanied by the ritual of traditional tea prepared with a one of more medicinal plants.

However, it became quickly became obvious that not a single family was doing the exact same thing. There were always the same basic tools, the same pestle and mortar, the same guampa,

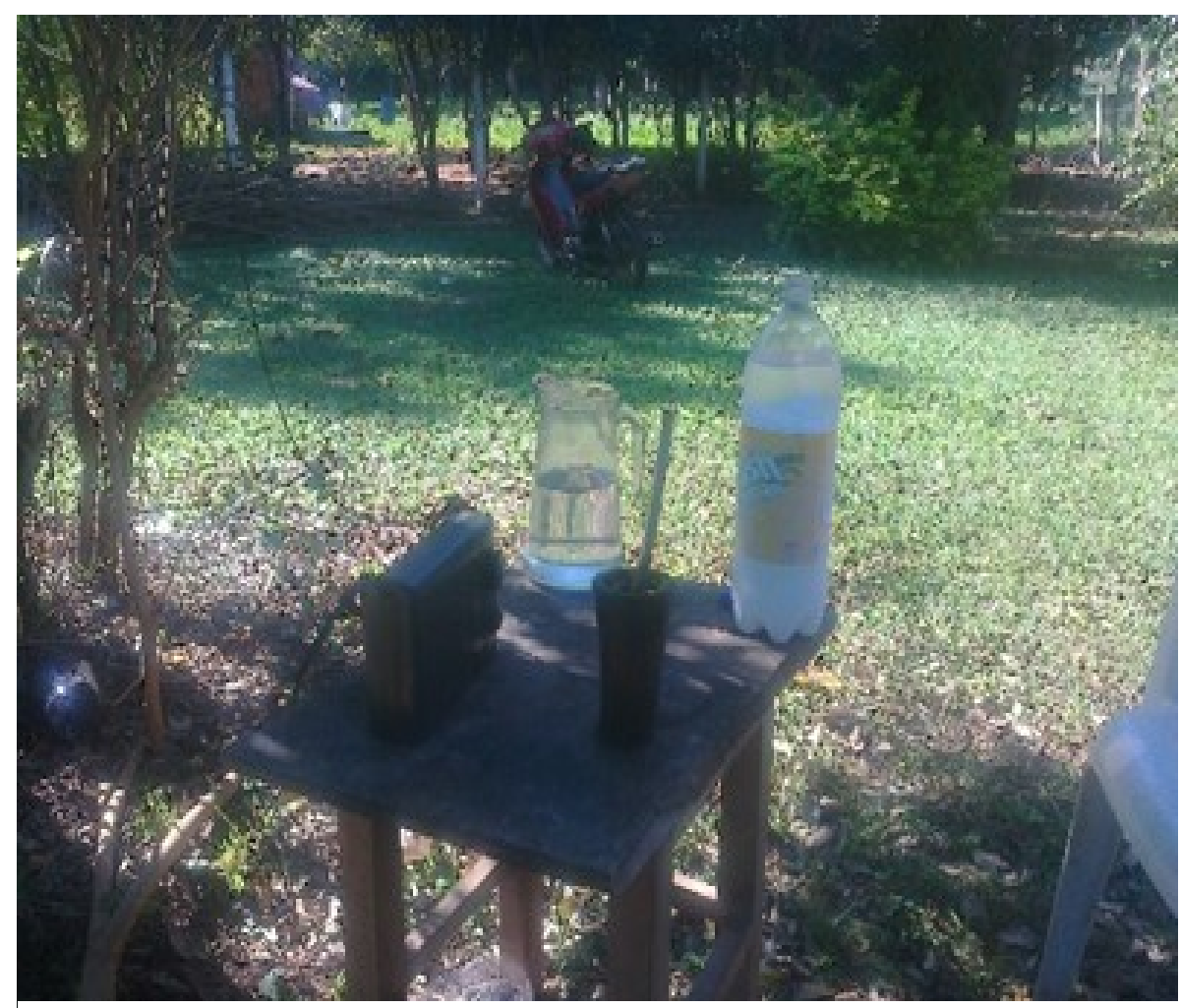

Figure 1.2. The traditonal guampa and mbombilla used for drinking terere and mate. Photo Credit Noah Goyke 
mbombilla and thermos (Figure 1.2), and often the same plants used fresh or dried. The ritual was similar, so similar as to initially seem the same to an outside observer, similar enough that neighbors across generations had not seen the differences for all the similarities, had missed the trees for the forest.

It was my place in the community, as friend and neighbor with the trust to talk openly combined with the perspective of an outsider to see things lost in the day-to-day bustle closer to home, that prompted me to investigate the use of traditional medicine in Chamorro Cué and the neighboring town of General Elizardo Aquino. My aim is not to make any sweeping generalizations about Paraguayans and medicine but to share what I observed with the friends and neighbors with whom I worked and lived (Figure 1.3).

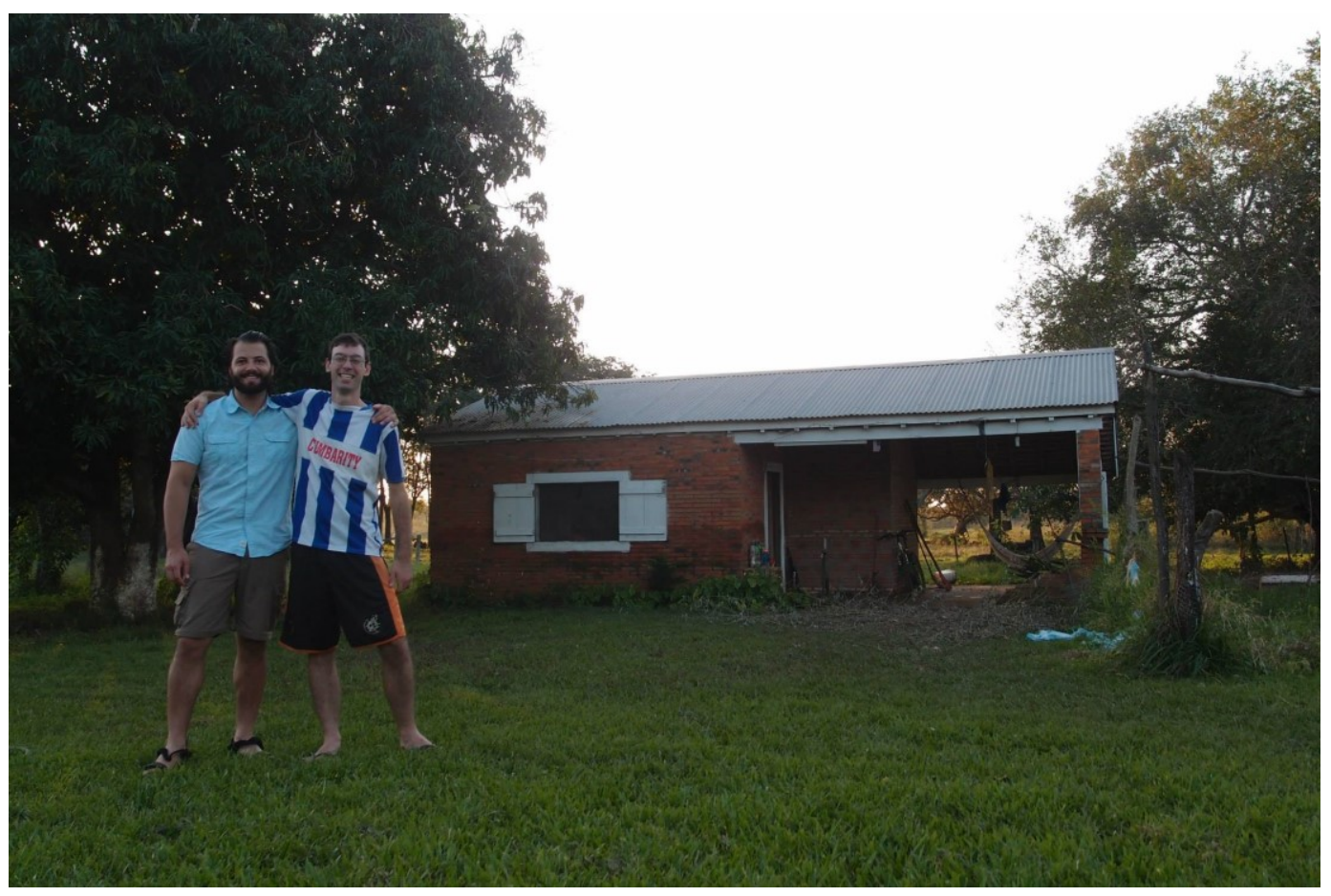

Figure 1.3. The Author's home in Chamorro Cue. Photo Credit Matthew Meglan 


\section{Introduction}

Rural Paraguay presents great opportunities for investigation into the subtle differences in the use of medicinal plants across seasons and the urban versus rural dichotomy in a rapidly globalizing society. This study is of particular interest because of the scale in which it is conducted, and the possible influence that micro-scale migration has on the differences between the urban and rural participants. Overall, medicinal plant use in Paraguay is poorly documented in the English-language scientific literature (Cámara-Leret et al. 2014, Albuquerque et al. 2013). The keywords "Paraguay" and "Ethnobotany" yield only five relevant results in searches of the online databases Web of Science (www.isiknowledge.com) and SCOPUS

(www.scopus.com). The subject is better documented in Spanish-language sources, in particular the nationally produced, peer-reviewed publication Rojasiana, which has produced twentythree articles on medicinal plant use in Paraguay in the last ten years. Yet many of the articles related to medicinal plant use in Paraguay tend to fall into three broad categories: ethnobotany in the ecologically distinct Chaco region (Arenas 2009, Arenas and Giberti 1987, SchmedaHirschmann 1993), studies of specific plants or applications (Li and Ohzumi 2004, González et al. 2009, Shimizu et al. 1987), and studies conducted in the municipal markets of Asuncion and other large towns (Degan et al. 2005, Basualdo et al. 2001, 2001, Benítez et al. 2008). Both of the first two types of articles focus primarily to exclusively on endemic plants, a serious oversight in ethnobotanic investigations (Bennet and Prance 2000). None analyze how the pharmacological repertoire changes seasonally or between place of residence. A review of traditional medicine in the Chaco concludes, "casi no existen estudios sobre estos temas ente la población no indígena chaqueña" [there almost do not exist studies about these topics among the non-indigenous Chaco population] (Arenas 2009). Considering the lack of ethnobotanic 
studies outside of the Chacho emphasizes the lack of ethnobotanical investigation into the nonindigenous population of eastern Paraguay.

Researchers are concerned that traditions of medicinal plant use are disappearing in a globalizing world (Voeks 2007, Cámara-Leret et al. 2014). In Paraguay, the anecdotal evidence for the continued strength of medicinal plant traditions suggests that those traditions are alive and well (Degen et al. 2005). This evidence includes the strong herb economy; 266 different species are found for sale in the municipal market of Asuncion, accounting for $6,405,000 \mathrm{Gs}$. in daily sales [Aug 10, $2015 \$ 1.00=5,220 \mathrm{Gs} ., \$ 1,227.01$ ] (ABC Color 2005). In addition to the economic evidence, catalogs and other information about medicinal plants are widely available and consumed (Silva Pedrozo 2012, Ibarrola Díaz and Degen de Arrúa 2014). However, the relationship between traditional and pharmaceutical medicine are poorly explored. This thesis uses the term traditional medicine to mean the use of plant-based medicines for their preventive or curative properties, and pharmaceutical medicine as compounds manufactured for their preventive or curative properties. The term traditional medicine is used because it is the English conjugate to the Spanish phrase "medicina tradicional" which was used with consistency by participants to describe all plant-based medicine.

One of the most interesting aspects of this study is the small-scale migration occurring around Paraguay, from small rural communities to nearby urban centers. Comparative studies of knowledge and use of traditional medicine before and after migration tend to focus on long distance migrations. (Ceuterick 2008, 2011, Ellena 2012, Halberstein 2005, Ramzan 2017, Pieroni 2005). In addition, those studies tend to focus on urban to urban migration rather than rural to urban migration. Alternatively, studies concerning local rural to urban migration tend to focus 
on social factors such as economic opportunities (Chant 1992, de Janvry, 2000) or else environmental impacts (Grau 2007).

This study addresses several gaps in the ethnobotanical literature of Paraguay. First, it compares medicinal plant use to pharmaceutical medicine between seasons and between place of residence. A study from nearby Brazil demonstrates that urban dwellers have significantly less knowledge of traditional medicine, and suggests it is due to pharmaceutical medicine use (Cunha Merétika 2010). This study also investigates the source of medicinal plants used between seasons and between place of residence. Finally, it documents the medicinal plants participants consider important for treating common ailments seasonally and the seasonally different important plants. I predicted that preference for pharmaceutical remedies would fluctuate seasonally (an increase during the winter cold season) and between the rural and urban populations (more pharmaceutical use in urban areas). I also predicted that the source of the remedies would vary by season and between urban and rural respondents, and that the plants considered important would change seasonally. The study reveals a remarkable homogeneity between the rural and urban populations, and subtle seasonal differences in traditional medicine use and plants used. 


\section{Study Context}

Within South America, Paraguay stands out as historically isolated, culturally distinct, and ecologically diverse. Together, these three factors have helped to keep the tradition of herbal medicine use an integral part of the national character. Understanding the historical context of medicinal plant use aids in understanding the continued role and importance of traditional medicine in $21^{\text {st }}$ century Paraguay.

Political isolation, particularly during the colonial and first several decades after independence necessitated that Paraguay develop a level of self-sufficiency unknown in much of the Latin American colonial world. Distance from the coast as well as Spanish economic policy under colonial rule effectively cut Paraguay off from material and intellectual exchange with Europe (Service 1954). Early governments of independent Paraguay also kept the nation isolated, first by choice and later as the result of a disastrous war (Washburn 1871) that witnessed the death of as much as $69 \%$ of the population (Whigham and Potthast 1999). Cut off from the influence of the rest of the world, Paraguayans were forced by necessity to cultivate and maintain selfsufficiency, including their traditional practice of medicinal plant use.

Early Spanish policy by settlement as opposed to pure mineral exploitation (Washburn 1871, Service 1954); resulted in the early emergence of a strongly Paraguayan culture neither entirely Spanish nor Guarani, but the emergence of an entirely new culture influenced by both. The rapid integration of the two cultures preserved the indigenous language, indigenous knowledge and indigenous customs. Today, approximately $90 \%$ of the population speaks indigenous Guarani and 90\% speaks Spanish (U.S. State Department, 2011). Indigenous knowledge and customs, including those related to traditional medicine use, have been better preserved in 
Paraguay than in countries where Spanish culture quickly supplanted those of indigenous peoples (Service, 1954).

Paraguay rests at the convergence of three distinct natural regions (the Gran Chaco, Pantanal and Atlantic Forest) and is divided into eleven distinct ecoregions (SEAM). Western Paraguay is divided into five distinct ecoregions and in eastern Paraguay there are six (Figure 3.1). The study area fell within an ecoregion of eastern Paraguay, in the transition zone $25 \mathrm{~km}$ from a bordering ecoregion in western Paraguay. The number of distinct ecoregions translates into incredible biodiversity in a small area. The Atlantic Forest is the second most diverse ecosystem in the world (WWF 2017), and the tremendous biodiversity of Paraguay yields in a staggering number of plants with possible medicinal applications. As many as 1,500 of the 15,000 vascular plant species estimated native species (Bausualdo et al. 1991).

Together, the convergence of the historical need for self-sufficiency, the preservation of indigenous traditions as a part of the distinct Paraguayan culture, and the diversity of flora in the many distinct ecosystems found in Paraguay influence the continued practice of traditional medicine as a part of daily Paraguayan life to some degree across all social and economic levels. 


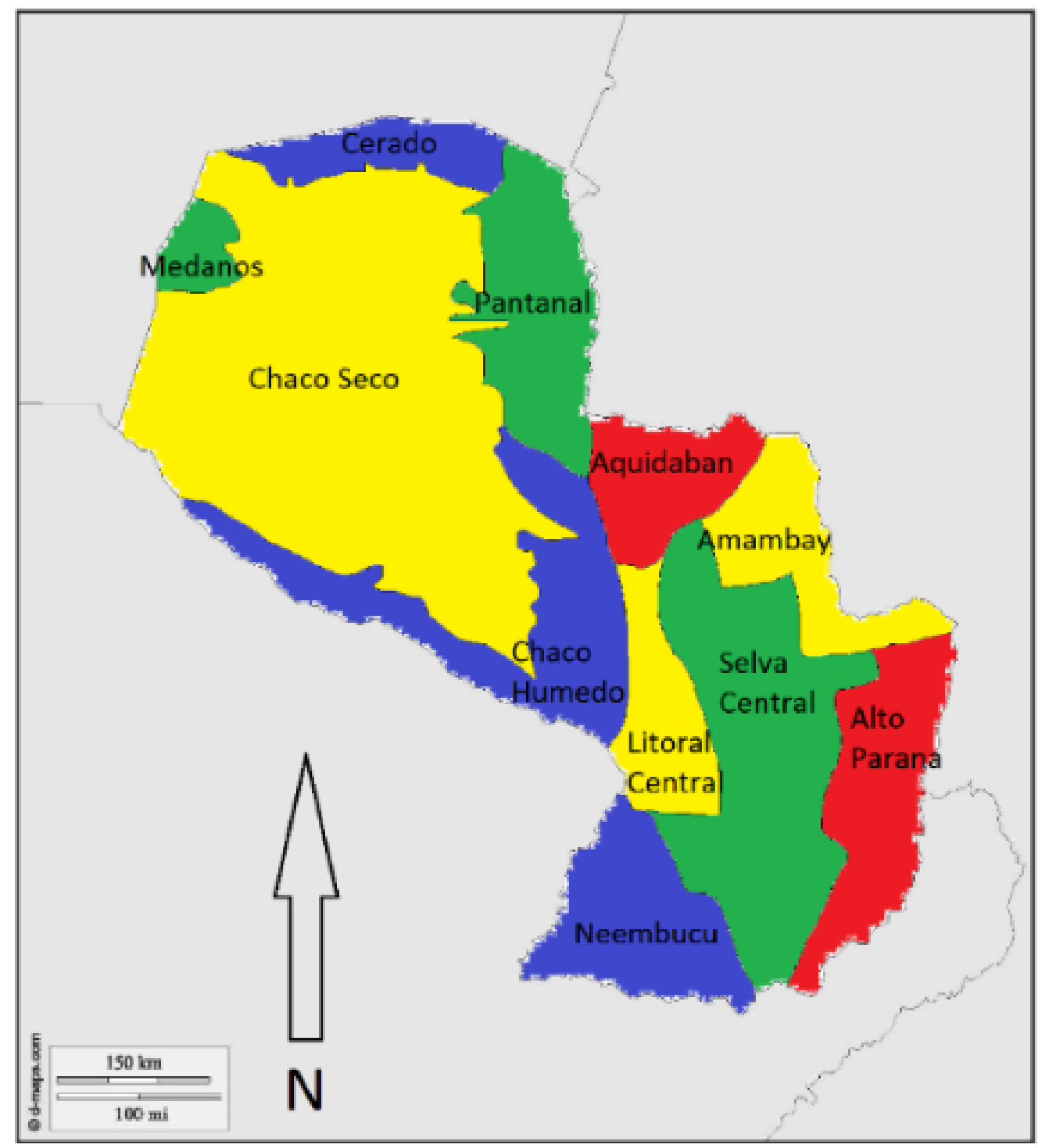

Figure 3.1. Ecoregions of Paraguay (map created by Noah Goyke, data from SEAM) 


\section{Methods}

\section{Study Area}

The study took place in Paraguay (Figure 4.1), Department San Pedro (Figure 4.2), District General Elizardo Aquino in both urban Gral. E. Aquino (-24.445972, -56.897578) and in the rural community of Chamorro Cué approximately 5 km away.

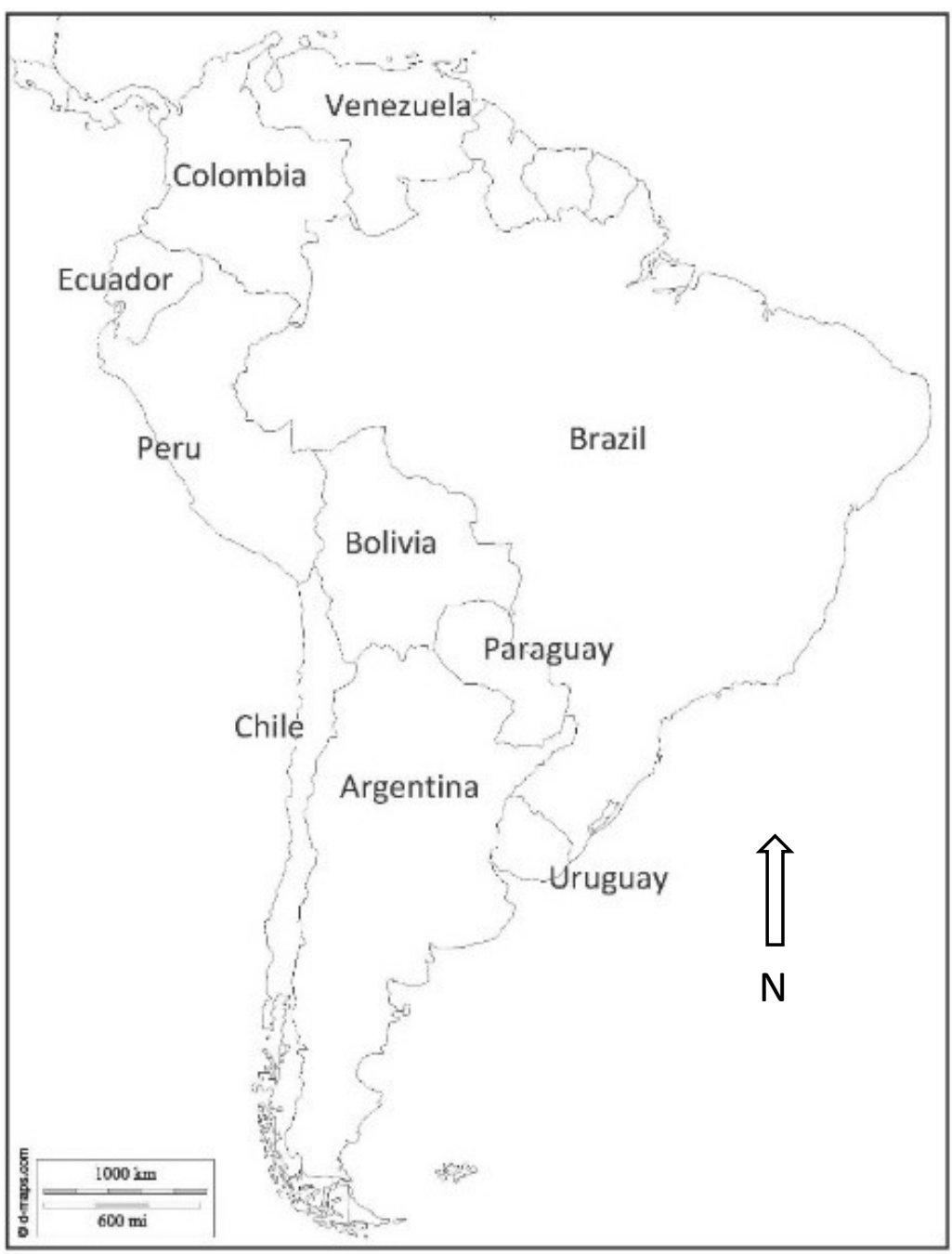

Figure 4.1. Paraguay in relation to South America (d-maps.com) 


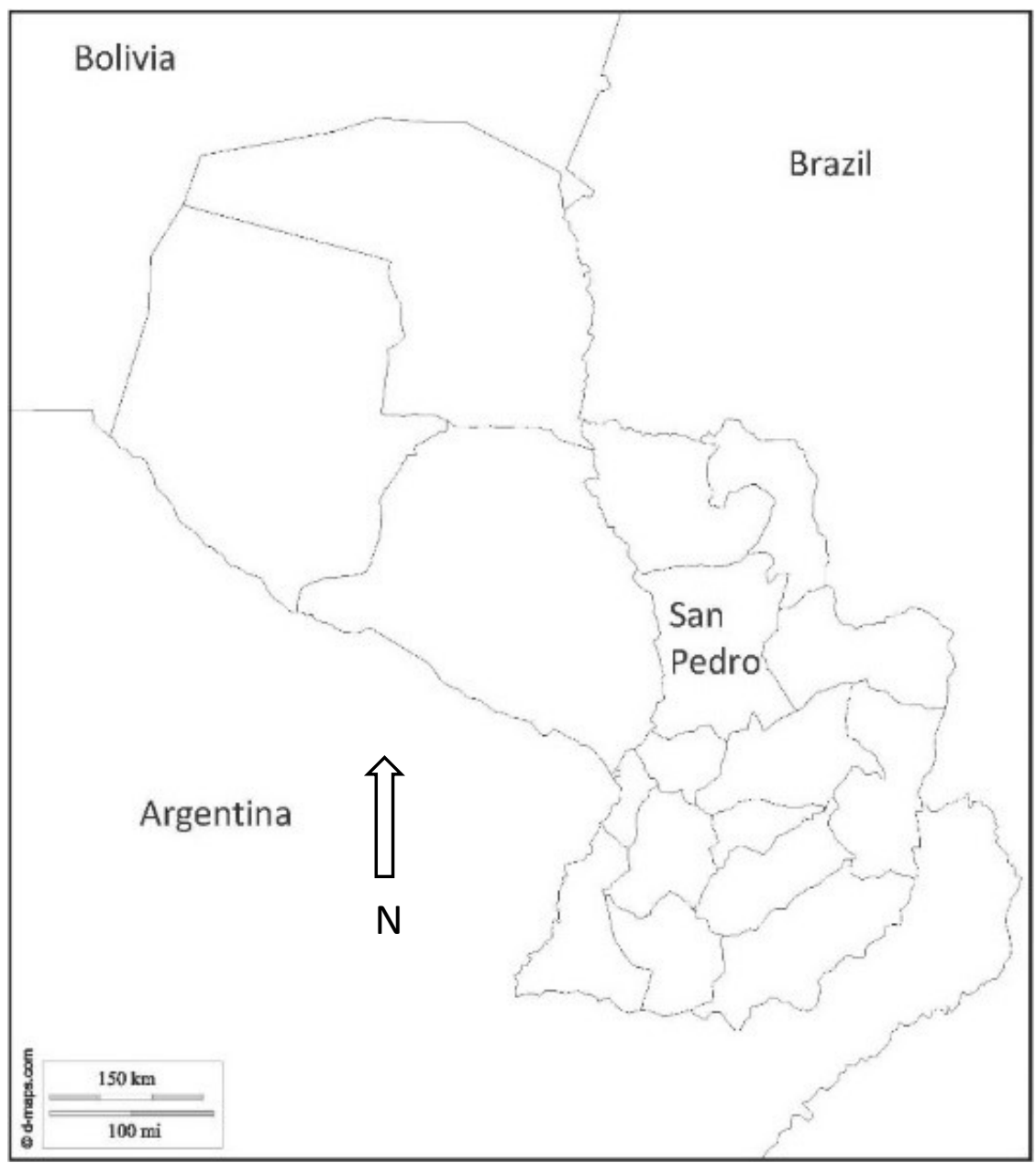

Figure 4.2. Department of Sand Pedro in relation to Paraguay (dmaps.com)

Population data for the urban area of Gral. E. Aquino are not available, however district level population data demonstrates a $5 \%$ increase in population from the year $2000(23,111)$ through $2015(24,195)$ (DGEEC, 2015). Aerial photography of the urban area from 2002 through 2015 reinforces that Gral. E. Aquino has grown at a faster rate in terms of area. The changing size of the urban center is the best approximation for town population that exists and represents approximately $66 \%$ growth (Figure 4.3). Much of that growth can be attributed to micro-level migration to the urban center from surrounding rural communities. This type of migration has increased since the end of the rule of General Alfredo Stroessner (1954-1989). During his 


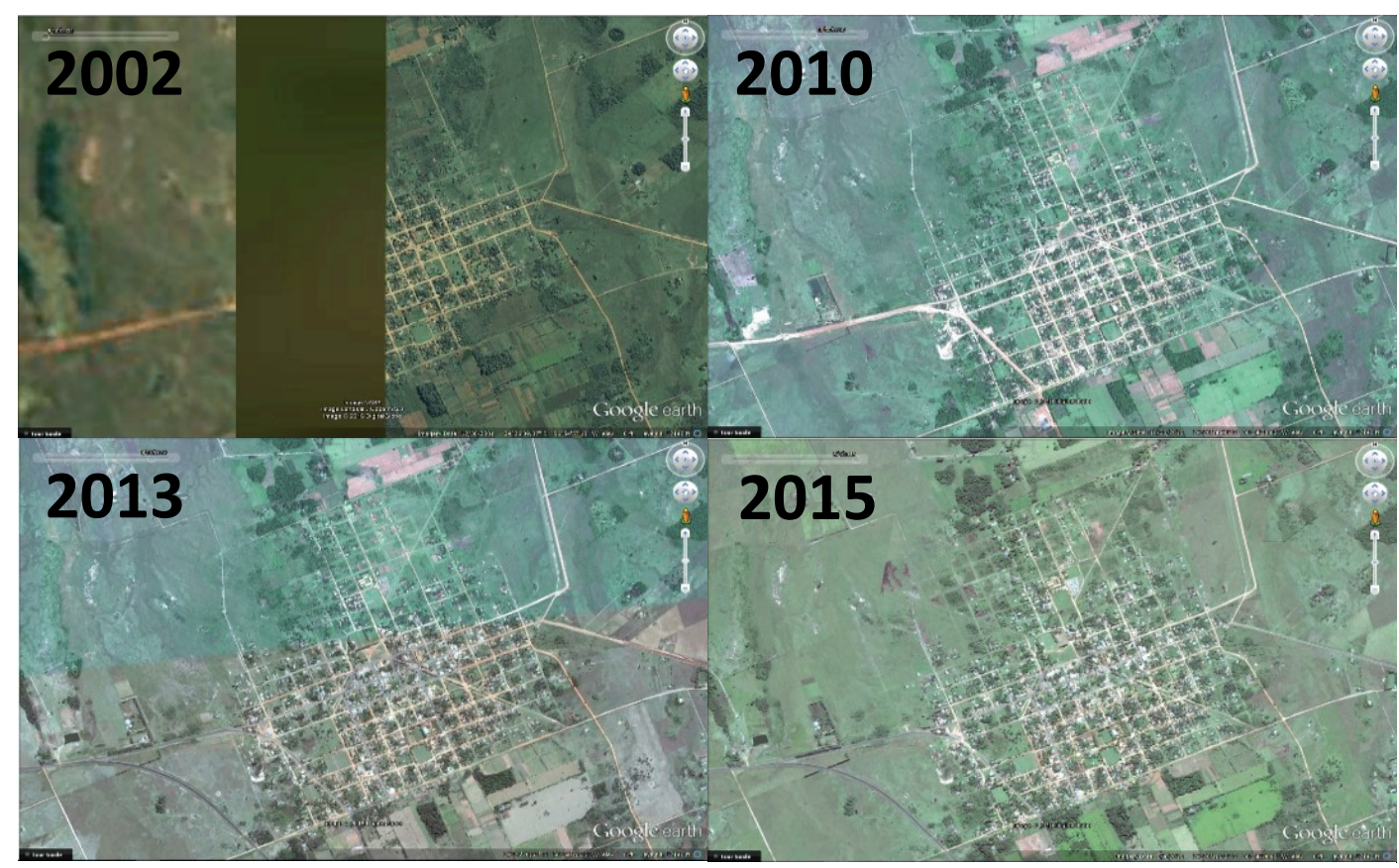

Figure 4.3. Growth of Gral. E. Aquino from the years 2002 to 2015. (Google Earth)

regime, the country was in a perpetual state of emergency, mobility was highly controlled by the government and the ability for families to migrate was limited. In the 1950 s to 1970 s internal migration from rural to urban areas was negative (Cerrutti 2003), in part spurred by the government policy of distributing land in rural areas to promote agrarian reform, with one of the specific target areas the department of San Pedro (Gillespie 1983). Not until late in his rule and afterwards did internal migration begin to move back into urban areas. Of the urban families interviewed, over half of the parents were born elsewhere than Gral. E. Aquino but had children born in the town, including one third who had been born in Chamorro Cué.

Official census gives Chamorro Cué a population of approximately 600, although a census conducted by the author suggests the actual population is closer to 450 . Of the adult male working population, eighty-six percent are farmers with a mix of subsistence crops (manioc Manihot esculenta, maiz [corn] Zea mays, beans Phaseolus vulgaris etc) and cash crops (sesame 
Sesamum indicum, chia Salvia hispanica, sunflowers Helianthus sp.) and some livestock. Eightysix percent of the adult female population are homemakers.

A brief comparison of the community during the time of the study to twenty years previously highlights the reality of Chamorro today and how it has changed over the years (Santacruz and Zárate, 2015). In 1995 the typical home was made of unbaked adobe or boards, had no electrical connection, and had either a well or a spring as a water source. The community population was 615 and the student body (grades K-6) was 122 at the local elementary school. The highway Ruta 10, the road to Gral. E. Aquino and ultimately the capital of Asuncion $(213 \mathrm{~km})$, was unpaved and trips to the capital could last over twenty-four hours depending on the weather. The only mode of transportation to the hospital was via horse or ox cart. Community economics were driven by cotton; the importance of the crop to the area is emphasized both by the name of the neighboring community Mandyju tygue, the Guaraní word for cotton and the name of the Departmental capital San Pedro de Ycuamandiyu (San Pedro of the Fountain of Cotton).

By $2000,95 \%$ of homes had an electrical connection and all homes had access to running water; both electrical current and running water reached the community in 1996. A decade later the majority of homes were made of kiln fired bricks at least in part and included a modern bathroom. Access to electricity and running water was total and the community had reliable cellphone service. According to the census from the the year 2000, the population peaked at 750 with 146 students in grades K-9. The cotton market eventually failed and the crop was replaced by a succession of other crops, none of which have had the stability and economic power of cotton. This market failure prompted some community members to migrate from Chamorro Cué in search of economic opportunities elsewhere, either with people moving 
internally to Gral. E. Aquino or larger urban centers or else abroad to Argentina (Parrado 2003) or Spain (Hierro 2013) or else nationally and especially locally to the urban center of Gral. E. Aquino. Work paving Ruta 10 finished in 2011, and automobiles replaced carts as the mode of patient transportation to the hospital. By 2015, the population had fallen to 450 people and school enrollment was down to just 48 students.

\section{Interviews}

Prior to the interviews informal preliminary conversations were conducted with a small sample of the perspective participants to determine their perceptions concerning traditional medicine use, which ailments were most frequent in the community and which were also treated with traditional medicine to some extent. The result of these informal preliminary interviews yielded thirteen common ailments that were included in the data collection interviews.

Thirty families in the rural community of Chamorro Cué were interviewed, and fourteen in the town of Gral. E. Aquino. The first interviews were conducted in the summer from Dec $15^{\text {th }}$ to March $15^{\text {th }}$ of 2015 and the second set of interviews were conducted with the same families in the winter from June $15^{\text {th }}$ to Sept $15^{\text {th }}$ of 2015 . Consent to participate in the interviews was verbal rather than written, owing to the combination of lower functional literacy among parts of the sample population, unfamiliarity with scientific research, and Guaranís history as an unwritten language. The waiver of written consent forms was permitted by the Michigan Technological University Institutional Review Board owing to the above circumstances in an effort to improve the quality of interviewee participation. All interviews were conducted after a preliminary visit and took place at a prearranged time at the family home. Verbal consent to participate was given at the preliminary visit and before the interview and all participants were advised that they had the right to withdraw from the interviews and any time. 
All of the interviews were conducted with families rather than with individuals. In each case there was a primary participant present for both of the interviews to ensure a level of consistency. Families were slightly smaller in Gral. E. Aquino than in Chamorro Cué. The number of generations on average two in both the rural and the urban community. (Table 4.1).

Table 4.1. Average Family Size and Generations per Family by rural and urban place of residence (average and confidence interval)

\begin{tabular}{lcc} 
& Generation & Family Size \\
\hline Rural & $2.10 \pm 0.25$ & $4.13 \pm 0.67$ \\
Urban & $1.79 \pm 0.33$ & $3.29 \pm 0.70$ \\
Average & $1.94 \pm 0.23$ & $3.71 \pm 0.55$ \\
\hline
\end{tabular}

* Overall is a weighted mean of Rural and Urban averages

The primary participant was not necessarily the head of the household, but was the family member considered most knowledgeable and practiced in administering traditional medicine, and most comfortable participating. Families were selected as the interview unit over individuals in order to capture the diversity of medicinal plant use across demographics, in particular gender and generational differences, which have been well documented in the literature (Thomas 2007, Voeks 2007). The rationale for this decision was the demographic differences in traditional medicine knowledge. Use can occur without individual knowledge (for example in children), as long as a single member of the household has access to that knowledge. The family ties and shared history of all participants would also suggest that knowledge of traditional medicine is approximately equal at the family level.

The interviews were semi-open ended and structured as a conversation between interviewer and interviewee (Bernard, 1995). Participants were not purposively selected for high ethnobotanical knowledge. The interviews were conducted in either majority Spanish or Guaraní, according to the preference of the interviewee, although Spanish was used to some 
extent in all cases. The time frame for the participants to consider was a period extending back no more than five years. Each interview lasted approximately one hour.

\section{Manner of Use for Traditional Medicine}

There are generally two ways in which members of the participant population use medicinal plants, either as preventive medicine to maintain health or as curative medicine to alleviate the symptoms and diseases. This study considers both types of traditional medicine use without distinguishing between them. Both types of medicine, but especially preventive, are often consumed directly as tea or else as an additive to yerba mate tea. Yerba mate (Ilex paraguariensis) is a plant in the holly family (Aquifoliaceae), native to South America, with caffeine content equivalent to coffee or tea and is alleged to have various additional health benefits (Bracesco el al. 2011). Adding medicinal plants to the yerba mate tea helps mask unpleasant flavors, controls dosage, and is an important social ritual in its own right (Heck and de Mejia 2007). Yerba mate tea is consumed many times a day, most days of the year, and nearly always with some medicinal plant, which is selected sometimes for general preventive properties in addition to those preventive properties attributed to yerba mate itself, or else simply for flavor. Yerba mate tea is drunk both hot and cold, and medicinal plant preference is influenced by this custom. Some plants are associated with either the hot or the cold version because of flavor. Bitter and sharp flavors such as wormwood and anis are preferred in the hot drink, while smooth flavors like mint, lemon grass and saffron are preferred in the cold. A question about the typical medicinal plants that each family used in their yerba mate tea was included to capture how plant use changed in particular across seasons. 


\section{Data Analysis}

The data collected through the oral interviews were analyzed in several different ways.

Categorical data were analyzed using Fisher's exact test in SAS 9.4 for Windows. The data were analyzed for the presence or absence of each ailment. The positive responses for presence were additionally analyzed based on the type of remedy used, either pharmaceutical, natural or a mix of both. All responses regarding the use of natural remedies were analyzed for the source of the remedy, either purchased, cultivated or collected wild. Each of the sets of data were analyzed by comparing between seasons and place of residence. Using G*Power the calculated power for this two-tailed Fisher's exact test $\left(n_{1}=30, n_{2}=14, \alpha=0.05\right)$ is 0.65 , indicating that the small sample size may lead to accepting a null hypothesis when a larger small size would have rejected it (Faul, 2014). There may be more differences than our study indicates. The discussion includes comments from participants and observations by the author to reinforce any conclusions drawn.

In addition, the data using were analyzed for relative importance (RI) as described by Bennett (2000) and Benítez (2008) by using number of responses and number ailments as test variables. Normalized values for responses (R) and ailments (A) are calculated for each plant by comparing the number of responses for that plant from the maximum number of responses for any plant, and the number of ailments treated with that plant to the maximum number of ailments treated by any plant. The responses to the questions about medicinal plants typically used in yerba mate tea were included in calculating the relative importance values.

$$
(R I)=\frac{(R)+(A)}{2} * 100
$$

$(\mathrm{RI})=$ Relative Importance

$(R)=$ Normalized Response Value $\left(R_{i} / R_{\max }\right)$

$(A)=$ Normalized Ailment Value $\left(A_{i} / A_{\max }\right)$ 


\section{Results and Discussion}

\section{Presence of Ailments by Season and Place of Residence}

Before comparing the use of pharmaceutical versus traditional medicine and analyzing the source of traditional plants or the plants used, it is important to analyze whether or not participants experience the common ailments and whether or not they experience them at different rates seasonally or across the rural or urban social divide (Table 5.1).

\begin{tabular}{|c|c|c|c|c|}
\hline & Summer & Winter. & Rural & Urban \\
\hline Cold & 77 & 89 & 87 & 75 \\
\hline Constipation & 66 & 64 & 67 & 61 \\
\hline Cough & 82 & 82 & 85 & 71 \\
\hline Diarrhea & 61 & 73 & 67 & 68 \\
\hline Fever & 75 & 82 & 82 & 71 \\
\hline Headache & 91 & 75 & 83 & 82 \\
\hline High Blood Pres. & s. 59 & 64 & $75^{*}$ & $32 *$ \\
\hline Kidney & $84 *$ & $59 *$ & $85^{*}$ & $43^{*}$ \\
\hline Pain & 68 & 68 & 72 & 61 \\
\hline Parasites & 72 & 77 & 72 & 89 \\
\hline Sore Throat & 91 & 89 & 88 & 93 \\
\hline Stomachache & 84 & 80 & 85 & 75 \\
\hline Urinary Pain & 66 & 59 & $80^{*}$ & $43^{*}$ \\
\hline
\end{tabular}

*: significant result $(\mathrm{p}<0.05)$

Analysis of the data revealed no statistically significant difference between presence of each ailment depending on the season, except those related to the kidney are significantly more common in the summer $(p=0.0171)$. This result is unsurprising considering that all remedies used in relation to the kidney are preventive rather than curative, and that kidney problems are typically associated with symptoms of over-hydration or under-hydration, which are both closely tied to summer heat. One key participant, a producer and vendor of medicinal plants, highlighted the importance of frequent urination along with abundant hydration in the summer months to keep the body in balance. 
Analysis for presence of the thirteen ailments across place of residence revealed that there is a statistically significant difference between the presence of kidney, urinary pain, and high blood pressure $(p=<0.0001, p=0.0171, p=0.0002$ respectively). All three of these ailments are related to lifestyle. Perceptions about ailments of the kidney relate them to heat and highlights that urban respondents are far more likely to spend their work and leisure time out of the heat, inside of office and homes, frequently with air conditioning. Urinary pain is perceived by respondents to be associated with spending long periods of time in the sun, which is most typical of men who work on small farms. Of the participants in this study $63 \%$ of rural families reported farming as their primary income source. None of the urban families did. Multiple participants attributed the condition, known locally as tihasy, to spending time in the sun without wearing appropriate clothing, particularly long sleeved shirts and closed toed shoes. Participants also cited bathing the feet immediately after removing shoes (rather than allowing them to cool off first) as a cause of urinary pain. High blood pressure, unlike kidney problems and urinary pain, is not specifically a heat issue, although the heat can have a role; it is primarily a diet issue. I observed over two years, eating with families from the study location on average four times a week, that the typical rural diet is higher in salt, sugar, oil and red meat consumption and lower in fruit and vegetable consumption than the urban diet, all of which contribute to high blood pressure.

The presence or absence of the remaining ailments is consistent across seasonal and urban versus rural differences. This is not surprising considering that preliminary interviews were conducted to identify the most common ailments experienced by the entire sample population. 
Use of Pharmaceutical and Traditional Medicine by Season and Place of Residence

One of the questions that this study investigates is whether or not the type of remedy used, pharmaceutical or traditional, changes with season or place of residence. Analysis of the data shows remarkable consistency both between seasons and place of residence, with the only statistically significant difference in preference found between rural and urban respondents for the treatment of parasites $(p=0.0431)$ (Table 5.2)

Table 5.2. Medicine type used by place of residence (as a percent of all participants).

\begin{tabular}{lllllll}
\multicolumn{9}{c}{ Rural } \\
\hline & Pharm. & Natural & Both & Pharm. & Natural & Both \\
\hline Cold & 25 & 46 & 29 & 10 & 38 & 52 \\
Constipation & 10 & 85 & 5 & 0 & 94 & 6 \\
Cough & 14 & 75 & 12 & 25 & 50 & 25 \\
Diarrhea & 15 & 68 & 18 & 21 & 63 & 16 \\
Fever & 51 & 24 & 24 & 60 & 25 & 15 \\
Headache & 64 & 10 & 26 & 83 & 13 & 4 \\
High Blood Pres. & 29 & 53 & 18 & 33 & 44 & 22 \\
Kidney & 2 & 94 & 4 & 8 & 92 & 0 \\
Pain & 65 & 21 & 14 & 71 & 18 & 12 \\
*Parasites & 21 & 70 & 9 & 48 & 40 & 12 \\
Sore Throat & 15 & 68 & 17 & 12 & 46 & 42 \\
Stomachache & 6 & 90 & 4 & 10 & 76 & 14 \\
Urinary Pain & 2 & 88 & 9 & 17 & 83 & 0 \\
\hline ringificant
\end{tabular}

*: significant result $(\mathrm{p}<0.05)$

Urban respondents more typically used pharmaceutical remedies to prevent or treat parasites, while rural respondents used traditional remedies more often. A decreased use in traditional medicine for treating parasites after migrating is consistent with the experiences of Colombian, Peruvian, and Bolivian migrants (Ceuterick 2008, 2011). Respondents consistently explained that children were typically the only ones to use anti-parasite medication. The education system supplies anti-parasitical medicine to all students, however respondents frequently reported that the medicine does not regularly reach rural schools. Urban parents also have much better access 
to anti-parasitical medication than their rural counterparts, both because of proximity to pharmacies and economic means.

Based on conversations and observations, it is unsurprising that the type of remedy did not generally change between seasons or locations. These conversations and observations suggest that community members consistently use over the counter medicine such as paracetamol [acetaminophen] and ibuprofen to treat colds, fevers, headaches and pain. Such medication is both inexpensive, as little as 500 Gs. per unit, and readily available. In Chamorro Cué there are six small stores that sell medications like these and the farthest a participant would have to travel to reach one is $1.5 \mathrm{~km}$, approximately a forty minute round trip walking. Distances are much shorter for most rural residents and a fraction of that distance for urban residents. This, juxtaposed with a one hour and forty minute walk to a regular pharmacy for the nearest of the rural participants. Rural and urban residents both thus typically employ natural remedies in place of more expensive or less readily available pharmaceuticals.

\section{Source of Medicinal Plants by Season and Place of Residence}

Analysis compared the source (purchased, cultivated, wild) of natural remedies in winter compared to summer and between rural and urban residents. Seasonally (Table 5.3), there is noticeable but not significant difference between the source of natural remedies for pain $(p=0.0550)$. In this case, half of respondents reported using medicinal plants they had cultivated in their yards or gardens, such as the leaf of the bitter orange (Citrus $\times$ aurantium) for pain relief, as well as Mentha piperita and Origanum vulgare. In the summer, no one reported using medicinal plants that they cultivated. C. $x$ aurantium leaves sprout in the winter and are preferred as a remedy when young and tender, M. piperita and $O$. vulgare are garden plants, 
and families typically only cultivate gardens in the months of March to October (spring through autumn).

Table 5.3. Natural remedy source by season (as a percent of all responses)

\begin{tabular}{lcccccr} 
& \multicolumn{2}{c}{ Winter } & \multicolumn{3}{c}{ Summer } \\
\hline Cold & Purchased & Cultivated & Wild & Purchased & Cultivated & Wild \\
Constipation & 17 & 44 & 38 & 19 & 45 & 36 \\
Cough & 41 & 38 & 21 & 43 & 35 & 23 \\
Diarrhea & 15 & 40 & 44 & 16 & 37 & 47 \\
Fever & 14 & 33 & 53 & 3 & 38 & 59 \\
Headache & 59 & 5 & 36 & 61 & 9 & 30 \\
High Blood Pres. & 32 & 26 & 42 & 25 & 42 & 33 \\
Kidney & 21 & 38 & 59 & 5 & 57 & 38 \\
Pain & 36 & 36 & 61 & 36 & 16 & 47 \\
Parasites & 19 & 14 & 67 & 15 & 0 & 19 \\
Sore Throat & 9 & 36 & 55 & 15 & 34 & 67 \\
Stomachache & 27 & 12 & 61 & 31 & 15 & 51 \\
Urinary Pain & 3 & 42 & 56 & 5 & 34 & 61 \\
$*$ Yerba Mate & 35 & 24 & 41 & 7 & 22 & 71 \\
\hline
\end{tabular}

*: significant result $(\mathrm{p}<0.05)$

Additionally, medicinal plants most frequently added to yerba mate tea were purchased more frequently in the winter than in the summer $(p=0.0002)$. The three most commonly reported medicinal plants used in the summer, Gomphrena decumbens, Dorstenia brasiliensis, Alternanthera pungens, are almost exclusively collected wild during the summer season and then used immediately. Only once in my three years in Paraguay did I see G. decumbens and $A$. pungens available for sale dried and preserved. In comparison, the three most commonly reported medicinal plants used in the winter, Pimpinella anisum, Matricaria recutita, Peumus boldus, are traditionally grown and harvested in the summer, dried, and then saved for consumption in the winter. Medicinal plants that are consumed dried are typically preserved by businesses and then sold, rather than being raised, harvested and dried at the home level. A key informant in this practice was a neighbor who cultivated various medicinal plants. He described which plants could be effectively dried and preserved without losing their desired properties. 
Between rural and urban residents, the differences in source of medicinal plants were most notable in remedies for diarrhea $(p=0.0252)$ and the plants used in yerba mate tea $(p=0.0089)$ (Table 5.4) In both cases urban residents would more often purchase medicinal plants, while rural people would more often collect them wild. Prices for fresh remedies typically fall between 500 and 2,000 Gs.; most supermarkets sell them for 700 Gs. per unit. Prices for dried remedies also very, Matricaria recutita for example sells for 4,950 Gs. for $50 \mathrm{~g}$ packages and Rosa banksiae sells for 2,100Gs. for a 15g package. A rural farmer's income is around 5,000,000Gs. per month.

In the case of diarrhea, both rural and urban dwellers use cultivated remedies such as the rind of Punica granatum. The wild remedy Pluchea sagittalis was reported as a treatment for diarrhea by forty percent of rural families. P. sagittalis in particular and wild remedies for diarrhea in general are simply not available in Gral. E. Aquino for wild collection by urban residents. The same holds true in the case of plants used in yerba mate tea; in urban areas plants harvested wild are simply not available. Urban residents also expressed a preference for simply purchasing medicinal plants for daily use in their yerba mate tea from street corner or door-to-door vendors for convenience. In rural areas, small stores where medicinal plants are available for purchase are much less conveniently located, which also discourages rural residents from buying them on a daily basis for use with yerba mate tea. In Chamorro Cué the store most well supplied with medicinal plants is located in the center of the community, more than a mile round trip for families on the edges of the community, but even there the availability of a given medicinal plant was not assured. 
Table 5.4. Natural remedy source by place of residence (as a percent of all responses)

\begin{tabular}{|c|c|c|c|c|c|c|}
\hline & \multicolumn{3}{|c|}{ Rural } & \multicolumn{3}{|c|}{ Urban } \\
\hline & urchased & Cultivated & Wild & Purchased & Cultivated & Wild \\
\hline Cold & 14 & 44 & 42 & 27 & 45 & 27 \\
\hline Constipation & 36 & 36 & 27 & 54 & 38 & 8 \\
\hline Cough & 15 & 40 & 44 & 17 & 35 & 48 \\
\hline *Diarrhea & 4 & 32 & 64 & 22 & 44 & 33 \\
\hline Fever & 53 & 8 & 39 & 89 & 0 & 11 \\
\hline Headache & 28 & 32 & 40 & 33 & 33 & 33 \\
\hline High Blood Pres. & 4 & 49 & 47 & 0 & 25 & 75 \\
\hline Kidney & 31 & 17 & 53 & 27 & 20 & 53 \\
\hline Pain & 55 & 20 & 25 & 50 & 17 & 33 \\
\hline Parasites & 13 & 16 & 71 & 28 & 17 & 56 \\
\hline Sore Throat & 9 & 33 & 58 & 18 & 38 & 44 \\
\hline Stomachache & 25 & 14 & 61 & 42 & 13 & 46 \\
\hline Urinary Pain & 3 & 35 & 61 & 8 & 50 & 42 \\
\hline *Yerba Mate & 14 & 25 & 61 & 39 & 18 & 42 \\
\hline
\end{tabular}

$*$ : significant result $(p<0.05)$

The similarity between the sources of remedies for winter and summer is best explained by the diversity of flora in Paraguay. The high diversity of Paraguayan flora results in a wealth of different plants used to treat any given ailment, some of which are available all year round but many of which are available seasonally. The case of stomachaches provides an excellent example. Of the twenty-seven plants reported, five were harvested wild in the winter only and five were harvested wild in the summer only. Several others were more commonly often harvested wild in one of the two seasons, Pluchea sagittalis in the summer and Peumus boldus in the winter. Nine of the reported plants are not harvested wild. Additionally, those who collect plants from their gardens or from cultivated plants around their homes often do so all year round, particularly in the case of perennial woody species such as $C$. $x$ aurantium, $C$. reticulate, Cajanus cajan, Carica papaya, Persea Americana, and Psidium guajava. It is important to note that all of these plants are comestible as well as medicinal (Bennet and Prance, 2000). 


\section{Plants Used by Season and Place of Residence}

A total of 171 different medicinal herbs, with 1,674 total responses in which traditional herb usage was mentioned. In the summer 127 different medicinal plants were reported with a total of 780 responses and 146 plants were reported in the winter, with 894 total responses. The relative importance of the plants reported was calculated and the results for the top 18 (RI) scores are reported in Table 5.5 and Figures 5.2 and 5.3.

Table 5.5. Relative importance of eighteen most important plants, with (A) and (R) values and (RI) values for summer and winter.

\begin{tabular}{llllll} 
& $(\mathrm{RI})$ & $(\mathrm{A})$ & $(\mathrm{R})$ & $(\mathrm{RI})$ Summer & $(\mathrm{RI})$ Winter \\
\hline Citrus $\times$ aurantium & $97^{*}$ & $100^{*}$ & $95^{*}$ & $78^{*}$ & $91^{*}$ \\
Pluchea sagittalis & $84^{*}$ & $69^{*}$ & $100^{*}$ & $65^{*}$ & $78^{*}$ \\
Matricaria recutita & $80^{*}$ & $88^{*}$ & $73^{*}$ & $65^{*}$ & $77^{*}$ \\
Verbena bonariensis & $73^{*}$ & $81^{*}$ & 64 & $64^{*}$ & $65^{*}$ \\
Eucalyptus sp. & $70^{*}$ & 50 & $90^{*}$ & 42 & $75^{*}$ \\
Pimpinella anisum & $66^{*}$ & $56^{*}$ & $76^{*}$ & 47 & $69^{*}$ \\
Mentha piperita & $62^{*}$ & $75^{*}$ & 49 & $59^{*}$ & $51^{*}$ \\
Aloysia polystachya & $59^{*}$ & $56^{*}$ & 61 & $66^{*}$ & 38 \\
Acicarpha tribuloides & $57^{*}$ & 31 & $83^{*}$ & $59^{*}$ & 39 \\
Gomphrena decumbens & $57^{*}$ & $56^{*}$ & 58 & $55^{*}$ & 48 \\
Phyllanthus niruri & $57^{*}$ & 44 & $69^{*}$ & $79^{*}$ & 22 \\
Salvia officinalis & $57^{*}$ & 44 & $69^{*}$ & 42 & $54^{*}$ \\
Psidium guajava & 55 & 44 & 66 & $55^{*}$ & 41 \\
Artemisia absinthium & 54 & $56^{*}$ & 53 & $55^{*}$ & 42 \\
Cecropia pachystachya & 53 & 50 & 56 & 38 & $53^{*}$ \\
Peumus boldus & 51 & 25 & $76^{*}$ & 32 & $51^{*}$ \\
Chenopodium ambrosioides & 50 & 50 & 51 & $62^{*}$ & 28 \\
Dorstenia brasiliensis & 50 & 31 & $69^{*}$ & 45 & 42 \\
\hline
\end{tabular}

*: Indicates inclusion in the top ten values 


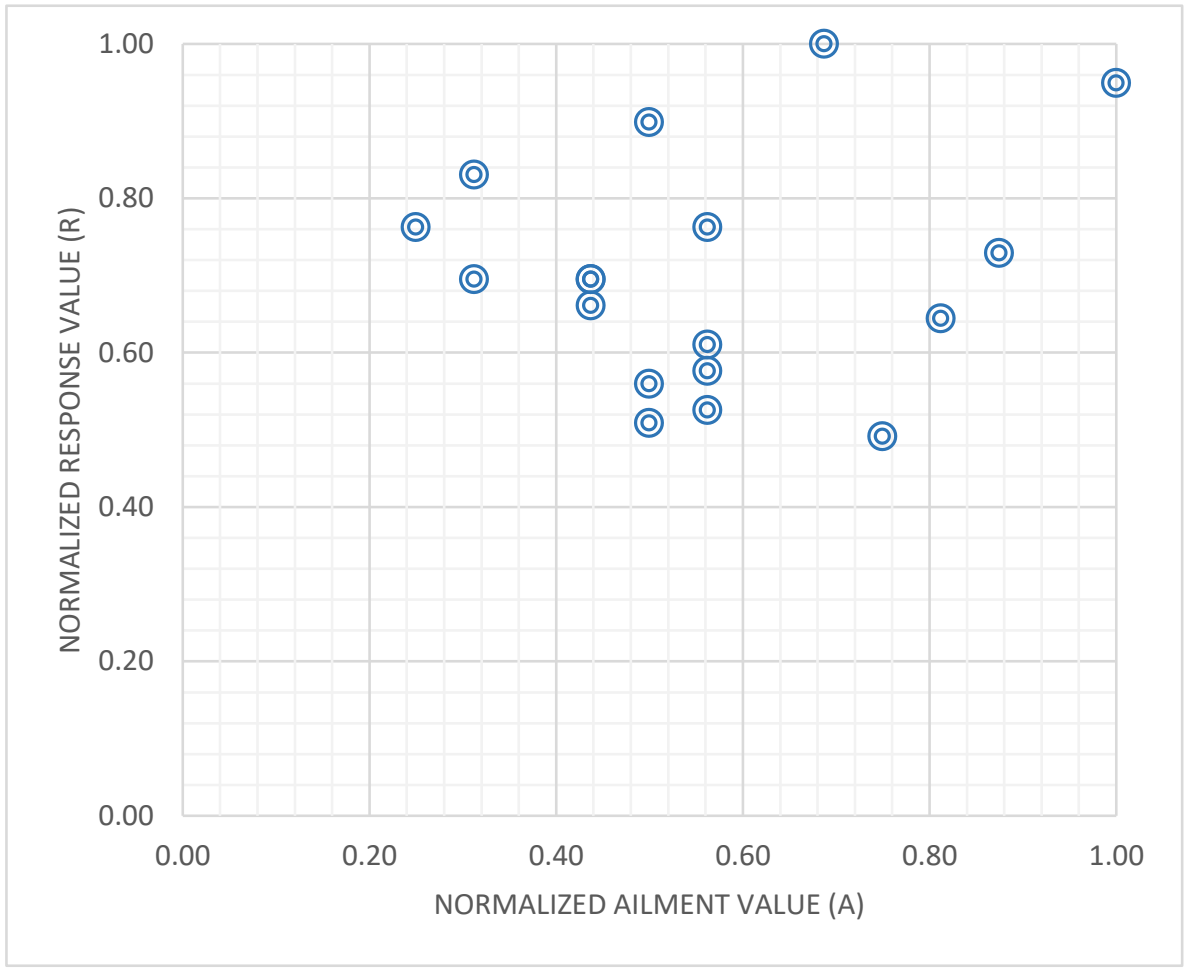

Figure 5.1. Distribution of the 18 plants with the highest (RI) by (R) and (A) values.

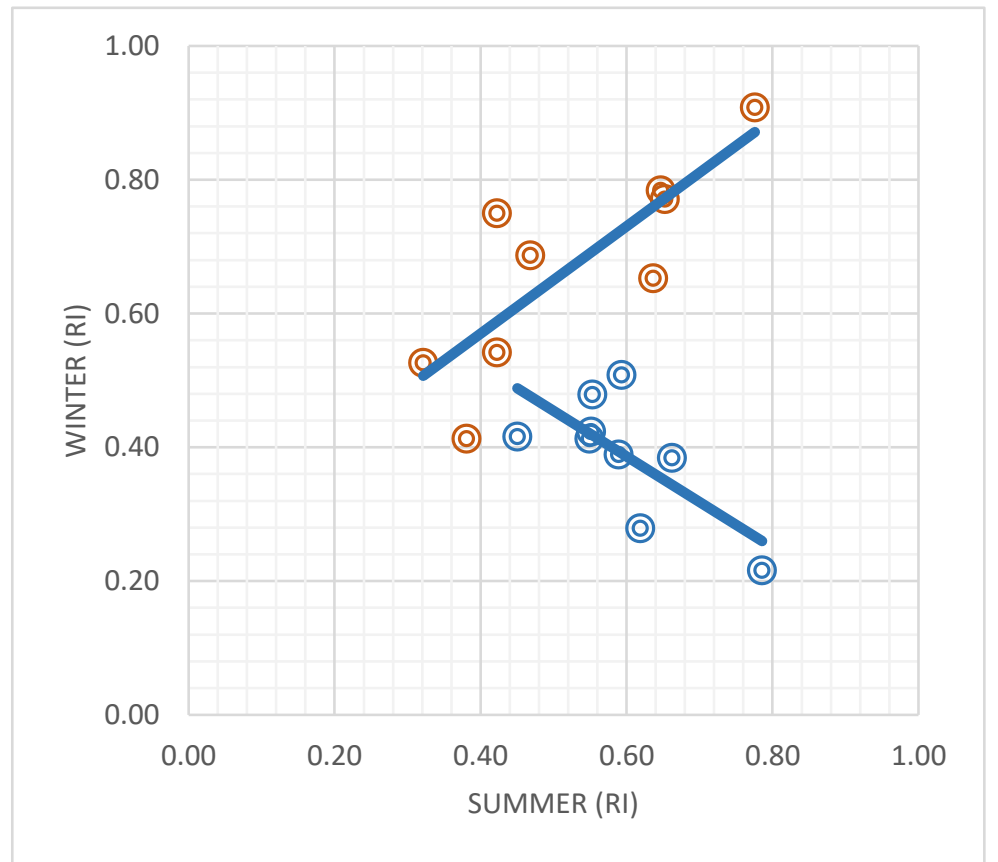

Figure 5.2. Distribution of the 18 plants with the highest (RI) by Winter (RI) and Summer (RI) values, and series defined by greater Summer (RI) or Winter (RI) values. 
There is a weak correlation between $(A)$ and $(R)$ values for the most important plants reported $\left(r^{2}=0.017, p=0.6066\right)$. The only relationship between the variables is that important plants have high (A) and (R) values; only two of the top ten (A) scoring plants do not appear in the top eighteen (RI) scores, and none of the top ten (R) scoring plants failed to appear in the top eighteen scores.

There is a weak correlation between the summer and winter (RI) values for the eighteen most important medicinal plants: $\left(r^{2}=0.0002, p=0.9613\right)$. However, when split into two groups, the plants with higher winter (RI) scores $(n=9)$ and those with higher summer (RI) scores $(n=9)$, linear trends become apparent. The plants with higher winter (RI) scores show strong, direct linear correlation with higher with their summer $(\mathrm{RI})$ scores $\left(r^{2}=0.7037, \mathrm{p}=0.0047\right)$. The direct correlation between increasing winter (RI) score and summer (RI) score reflects the general trend for all medicinal plants reported. For the other group of plants, in which summer (RI) scores are greater than winter (RI) scores, the correlation is also strong but inverse $\left(r^{2}=0.4729\right.$, $\mathrm{p}=0.0406)$. An increase in summer (RI) score for plants in this group correlates to a decrease in their winter (RI) score. Two distinct factors in how Paraguayan people consume medicinal plants illustrate why the different trends exist in the two groups of plants.

It is impossible to separate entirely the two factors about consumption that help explain the different trends in the groups that have higher summer and winter (RI) values. Socially, the habit consuming medicinal plants as a part of yerba mate tea influence which medicinal plants are preserved for consumption and which are not. The economic and agronomic ability to preserve effectively specific medicinal plants at scale influences consumption of yerba mate tea. Both factors are also as strongly related to cultural values entirely apart from preventive and curative medicinal considerations. 
The first of these two factors is the preferred method for consuming medicinal plants via additives to yerba mate tea. In the case of all eighteen of the top scoring plants, yerba mate tea is either the typical or the exclusive way people consume them. So important is yerba mate tea culturally, and so important the distinction between the hot and cold variety, that there are distinct verbs in the indigenous Guarani for drinking the hot [aterere] and cold [akay'u] versions. Most traditional medicinal herbs are added to either the hot or cold versions, but not both. Verbena bonariensis for example is common as an additive to either the hot or the cold tea, but that is atypical. The cold version of the tea is almost exclusively consumed in the hot summer months, which would explain why the plants that have higher (RI) values in the summer have correspondingly lower winter (RI) values. Two examples are Gomphrena celosioides/ and Phyllanthus orbiculatus, which I never observed used with hot yerba mate tea and as such, their use in the cold winter months is only intermittent. Most families consume hot yerba mate tea year round, during the early morning hours all year and throughout the day in the cold winter months. This helps explain why the medicinal plants that are more important in the winter continue to have high importance in the summer; they are added to hot yerba mate tea, which is consumed daily.

Second, some medicinal plants are consumed fresh while others are consumed dried. Plants used in cold yerba mate tea, which hence have higher summer (RI) scores are not typically preserved but are instead collected wild. Examples include Dorstenia brasiliensis, Gomphrena celosioidesl, Psidium guajava, and Phyllanthus orbiculatus. Conversely, it is more typical that plants used in hot yerba mate tea are harvested seasonally and persevered for year round use. Examples include Matricaria chamomilla, Peumus boldus, and Pimpinella anisum. 


\section{Singly Reported Plants}

It is worth noting that forty-two of the plants reported during the interviews scored the lowest possible (RI) value. Several of these plants are undocumented in the peer-reviewed literature. These plants, many of which were reported one time for the use of one ailment are considered singly reported, each one representing one of the 1,674 total responses. Singly reported plants were more frequent in the winter than in the summer, and more frequent in rural as opposed to urban areas (Table 5.6). The likely explanation is that medicinal plants are consumed more in the winter season, a consensus of all participants, and that people in rural areas have access to many more plant species in the fields and around their homes than urban dwellers. The largest number of singly reported plants reported by a single family was five, and the most typical response was one. This suggests no family has a vastly different or more expansive knowledge than the others. Even families that included individuals identified by community members as being exceptionally knowledgeable did not deviate significantly in their use than other families in the community. The lack of concentration of singly reported plants in one or a few families reinforces the notion that the population is homogenous in its application of traditional knowledge.

Table 5.6. Number of singly reported responses by season and place of residence.

\begin{tabular}{lccc} 
& Summer & Winter & Total \\
\hline Urban & 3 & 6 & 9 \\
Rural & 15 & 18 & 33 \\
Total & 18 & 24 & 42 \\
\hline
\end{tabular}

Finally, one of the most interesting things to become apparent during the data analysis is the importance and specificity of medicinal plants used to control bowel movements. Of the plants with the highest importance value being used to treat a single ailment per season three of the top seven are used to treat constipation, one of the top seven is used to treat diarrhea and an 
additional one is reported to treat either constipation or diarrhea depending on the season (Table 5.7). Of the three treatments for constipation none are used with any distinction between seasons or place of residence, and they were the only medicinal plants, other than fruit in general, suggested by any considerable number of respondents. The case of diarrhea was similar, only remedy other than Meliccus lepidopetalus was noted by a high number of participants. Further, four of the responses with the lowest possible importance score were also reported for diarrhea (Fragaria x ananassa, Glandularia peruviana, Melissa officinalis, Rheum rhabarbarum) with an additional one singly reported response (Phaseolus vulgaris) for constipation treatment. The concentration of responses concerning bowl movement ailments in a few key plants, especially ones not used to treat other ailments effectively highlights the high homogeneity of traditional knowledge and traditional medicine use across places of residence.

Table 5.7. Relative importance of seven most important plants reported as being used to treat one ailment per season

\begin{tabular}{ll} 
& $(\mathrm{RI})$ \\
\hline \#Cassia angustifolia & 23 \\
\#Rosa banksiae & 22 \\
Alternanthera ficoidea & 22 \\
Passiflora caerulea & 16 \\
\#*Punica granatum & 15 \\
\#Linum usitatissimum & 12 \\
*Melicoccus lepidopetalus & 11 \\
\hline *: Indicates use for treatment of diarrhea \\
\#: indicates use for treatment of constipation
\end{tabular}




\section{Conclusions}

The similarity between summer and winter behavior and between urban and rural residents highlights the relative homogeneity of the population, a predictable homogeneity based on the evidence of micro-migrations from rural communities, including Chamorro Cué, into urban Gral. E. Aquino. No example points out this fact more strongly than constipation, where a handful of remedies unique to the treatment of diarrhea are popular among both urban and rural respondents.

The differences in the presence of ailments seasonally and between places of residence were rooted in lifestyle. Changes in preventive medicine use for kidney problems between seasons and residence stemmed from perceptions related to summer heat, as did the urban and rural differences in the use of curative medicine for urinary pain. Increased reports of high blood pressure among the rural population relates to lifestyle, specifically diet, differences between the two locations.

Social factors also explain the lone difference in preference for pharmaceutical or traditional medicine, for parasite treatment between urban and rural residents. The urban preference for pharmaceutical remedies is the logical outcome of children being the most frequent users of anti-parasitical medicine and that urban schools provide pharmaceutical anti-parasitical medicine on a regular basis. In rural areas, schoolchildren receive the anti-parasitical medicine irregularly, if at all, and purchase of the same medicine at a private pharmacy is out of many families physical and economic reach. Ailments for which pharmaceutical remedies are preferred year round and by both rural and urban residents are those with inexpensive, over the counter treatments. 
Access explains differences in the source of medicinal plants, just as it does the rural preference for traditional parasite remedies. Urban residents have a slight preference for buying medicinal pants, a preference which becomes significant in the case of diarrhea remedies and the plants used with yerba mate tea. This preference is in part due to the easy accessibility to vendors. The same holds true in the case of plants for yerba mate tea, the plants consumed in the winter are more available for purchase and less available wild, than during the summer season. The outlier is medicinal plants used to treat pain. The seasonal change, a winter drop in purchasing remedies in favor of growing them in the garden, is in line with the general trend of gardening being a primarily a winter activity.

Finally, cultural factors best explain the differences in seasonal use of the most important medicinal plants. The importance of the difference in hot and cold yerba mate tea, and the importance of drinking the hot tea year round but the cold tea only seasonally is one of those factors. The other factor is the preference for fresh plants in the cold tea, while the hot tea is often prepared with preserved plants. The result is that important plants that are more important in the winter than summer are also important in the summer, but that plants that are more important in the summer have low, inverse importance in the winter.

Modern conveniences seem to be reaching the rural community as quickly as they are reaching the nearby urban community, in the form of medicine as well as infrastructural improvements. Still, the relative homogeneity of the two populations in the way they use the medicinal plants, even in light of modernization, seems to indicate that into the near future the tradition of herbal medicine will remain strong and important in eastern, rural Paraguay. 


\section{Bibliography}

ABC Color. Remedios yuyos mueven más de G. 6 millones por día en Mercado 4. ABC Color. 4 Sept. 2005. http://www.abc.com.py/edicion-impresa/economia/remedios-yuyosmueven-mas-de-g-6-millones-por-dia-en-mercado-4-854049.html web. 2 Feb. 2017.

Albuquerque U.P., J. Soares Silva, J. L. Almeida Campos, R. Silva Sosa, T. C. Silva, R. R. Nóbrega Alves. 2013. The current status of ethnobiological research in Latin America: gaps and perspectives. Journal of Ethnobiology and Ethnomedicine. 9(1): 72-80.

Arenas P. 1987. Medicine and magic among the Maka indians of the Paraguayan Chaco. Journal of Ethnopharmacology. 21(3): 579-295.

Arenas P. 2009. Los Estudios Sobre Medicina y Farmacopea Vernácula en el Gran Chaco. Rojasiana 8(2): 81-100.

Arenas P., G. C. Giberti. 1987. The Ethnobotany of Odontocarya asarifolia (Menispermaceae), an Edible Plant from the Chaco. Economic Botany. 41(3): 361-369.

Basualdo, I., E. Zardini, M. Ortiz. 1991. Medicinal Plants of Paraguay: Underground Organs. Economic Botany 45(1): 89 - 96.

Basualdo, I., E. Zardini, M. Ortiz. 1991. Medicinal Plants of Paraguay: Underground Organs II. Economic Botany 49(4): 387 - 394.

Benítez B., S. Bertoni, S. Pérez, F. González. 2008. Principales Especies Medicinales Comercializadas en los Mercados del Departamento de Paraguarí. Diversidad y Determinación de la Importancia Relativa.

Bennet B. C., and G. T. Prance. 2000. Introduced Plants in the Indigenous Pharmacopoeia of Norther South America. Economic Botany. 54(1): 90-102.

Bernard, H.R. 1995. Research Methods in Anthropology: Qualitative and Quantitative Approaches. $2^{\text {nd }}$ Ed. Walnut Creek: Altamira.

Braesco, N., A.G. Sanchez, V. Contreas, T. Menini, A. Gugliucci. 2011. Recent advances on Ilex paraguariensis research: Minireview. Journal of Ethnopharmacology. 136: 378-384.

Cámara-Leret, R., N. Paniagua-Zambrana, H. Balslev, M. J. Macía. 2014. Ethnobotanical Knowledge is Vastly Under-Documented in Northwestern South America. PLos ONE. 9(1): e85794

Cerrutti M., R. Bertoncello. 2003. Urbanization and Internal Migration Patterns in Latin America. Centro de Estudios de Población. Argentina.

Céspedes de Zárate, C. I., Z. Germán González, and G. Delmáas de Rojas. 2011. Aclimatación de las Especeses Baccharis crispa Spreng. "Jaguarete Ka'a” y Baccharis trimera (Less.) DC. 
"Jaguarete Ka'a", con Rango de Amenzaz, Usadas en Medicina Popular, Paraguay. Rojasiana 10: 63-79.

Chant S. 1992. Migration at the margins: gender, poverty and population movement on the Costa Rican periphery. Gender and migration in developing countries. London, England. Belhaven Press. 49-72.

d-maps. 2017. States (White). http://www.d-maps.com/carte.php?num car=2313andlang=en. web. 24 Feb. 2017.

d-maps. 2017. Boundaries, Departments (White) http://www.dmaps.com/carte.php?num car=4483andlang=en web. 24 Feb. 2017.

de Janvry, Alain. 2000. Rural poverty in Latin America: Determinants and exit paths. Food Policy. 25(4): 389-409.

Degen R., N. Soria, M. Ortiz, I. Basualdo. 2005. Problemática de nombres comunes de plantas medicinales comercializadas en Paraguay. Dominguezia 21(1): 11-16.

Ellena R., C. L. Quave, A. Pieroni. 2012. Comparative Medical Ethnobotany of the Senegalese Community Living in Turin (Northwestern Italy) and in Adeane (Southern Senegal). Evidence-Based Complementary and Alternative Medicine.

Faul, F. (2014). G*Power version 3.1.9.2, Universität Kiel, http://www.gpower.hhu.de/ downloaded 30 March 2017.

Gillespie, F. 1983. Comprehending the Slow Pace of Urbanization in Paraguay between 1950 and 1972. Economic Development and Cultural Change. 31(2): 355-375.

Google Earth. 2017. https://www.google.com/maps/@-24.4384287,56.9286689,15986m/data=!3m1!1e3 web. 24 Feb. 2017, 28 Feb. 2017.

González Y., M. I. Mercado, R. Degen, G. I. Ponessa. 2009. Morfoanatomía y etnobotánica de rizoma, tallo y escapo de "kapi'i kati", Kyllinga odorata (Cyperaceae) y sus sustituyentes de Asunción del Paraguay y alrededores. Lilloa 46(1-2): 58-67.

Heck, C.I., de Mejia, E.G. 2007. Yerba Mate (Ilex paraguariensis): A comprehensive Review on Chemistry, Health Implications, and Technological Considerations. Journal of Food Science. 72(9): 138-151.

Hierro, M. Latin American Migration to Spain: Main Reasons and Future Perspectives. International Migration. 54(1): 64-83.

Ibarrola Díaz, D., R. L. Degen de Arrúa. 2014. Catalogo llustrado de 80 plantas medicinales del Paraguay. Facultad de Ciencas Químicas Universidad Nacional de Asunción and Agencia de Cooperación Internacional del Japón (JICA). AGR S.A., Asunción.

Li Y., Y. Ohizumi. 2004. Search for Constituents with Neurotrophic Factor-Potentiating Activity form the Medicinal Plants of Paraguay and Thailand. The Pharmaceutical Society of Japan. 124(7): 417-424. 
Parrado E. A., Cerrutti, M. 2003. Labor Migrating between Developing Countries: The Case of Paraguay and Argentina. International Migration Review. 37(1): 101-132.

Pieroni A., H. Muenz, M. Akbulut, K. Hüsnü Can Başer, C. Durmuşkahya. 2005. Traditional phytotherapy and trans-cultural pharmacy among Turkish migrants living in Cologne, Germany. Journal of Ethnopharmacology. 102: 69-88.

Santacruz, R., and D. Zárate. 2015. Vida de la Escuela: Gda N 1883 Chamorro Cué Gral. E. Aquino Historia de la Comunidad Plan Anual del Director Año: 1.995.

Schmeda-Hirschmann G., 1993. Magic and medicinal plants of the Ayoreos of the Chaco Boreal (Paraguay). Journal of Ethnopharmacology. 39: 105-111.

SEAM. 2013. Resolución N 614/13. Por la Cual se establecen las Ecorregiones para la Regiones Oriental y Occidental del Paraguay. Secretaria del Ambiente Paraguay. Asunción.

Service, E. R. 1954. Spanish-Guarani Relations in Early Colonial Paraguay. University of Michigan Press, Ann Arbor.

Silva Pedrozo, J. 2012. Pohã ñana renda: Plantas medicinales. Ministerio de Education y Cultura. Asunción.

Shimizu M., H. Syunji, M. Arisawa, T. Hayashi, S. Suzuki, M. Yoshizaki, M. Kawasaki, S. Terashima, H. Tsuji, S. Wada, H. Ueno, N. Morita, L. H. Berganza, E. Ferro, I. Basualdo. 1987. Chemical and Pharmaceutical Studies of Medicinal Plants in Paraguay. I. Isolation and Identification of Lens Aldose Reductase Inhibitor from "Tapecúe," Acanthospermum austral O.K. Pharmecutical Society of Japan. 35(3): 1234-1237.

Thomas E., I. Vanderbroek, P. Van Damme. 2007. What Works in the Field? A Comparison of Different Interviewing Methods in Ethnobotany with Special Reference to the Use of Photography. Economic Botany. 61(4): 376-384

U.S. State Department. "Background Note: Paraguay". Archived from https://www.state.gov/r/pa/ei/bgn/1841.htm on 1 June 2011. Web. Retrieve 2 February 2017

Voeks R. 2007. Are women reservoirs of traditional plant knowledge? Gender, ethnobotany and globalization in northeast Brazil. Singapore Journal of Tropical Geography 8: 7-20.

Washburn, C. A. 1871. The History of Paraguay. Vol I. Lee and Shepard, Boston.

Whigham, T. L., and B. Potthast. 1999. The Paraguayan Rosetta Stone: New Insights into the Demographics of the Paraguayan War, 1864-1870. Latin American Review 34: 174-186.

WWF. 2017. Atlantic Forests, South America. http://wwf.panda.org/what we do/where we work/atlantic forests/ web. Retrieved 21 Feb. 2017. 


\section{Appendix A. SAS}

The data analysis for this paper was generated using SAS software, Version 6.2.9200 of the SAS System for Windows. Copyright @ 2013 SAS Institute Inc. SAS and all other SAS Institute Inc. product or service names are registered trademarks or trademarks of SAS Institute Inc., Cary, NC, USA.

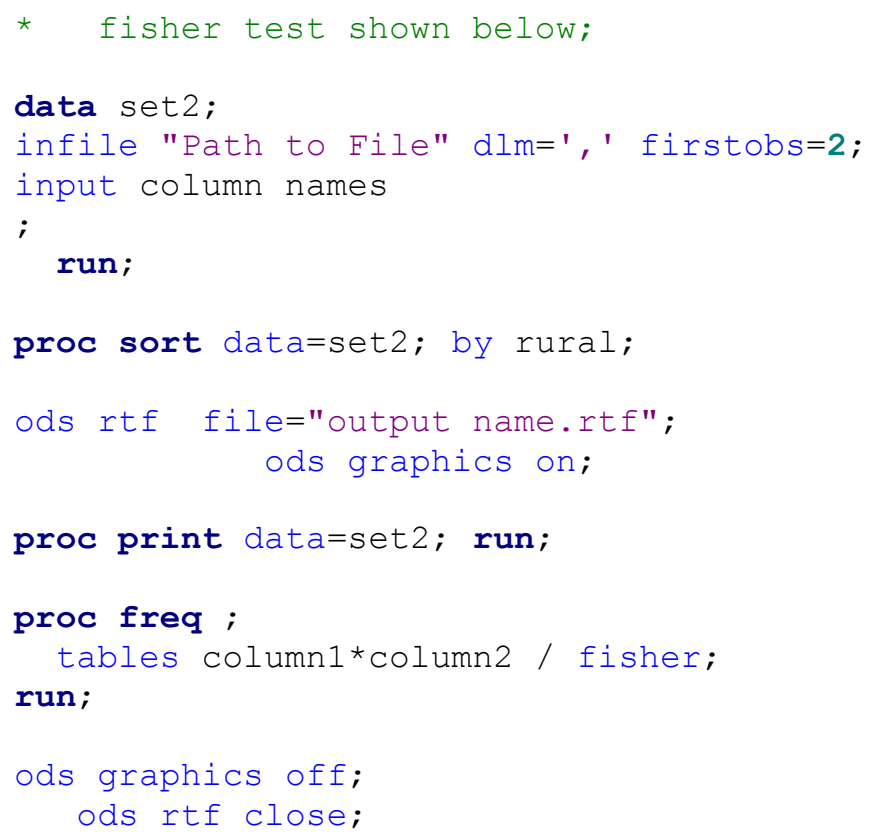




\section{Appendix B. Permissions}

1) Permission to use maps from d-maps.com - Figures 4.1 and 4.2

All the maps are protected by copyright.

They are free for any use, even commercial, in the following conditions:

- The exact URL where the original map comes from must be mentioned

- The number of used maps is limited to 10 for a publication (Web, DVD, book...)

- The number of used maps is unlimited with BeGraphic GIS use.

http://www.d-maps.com/conditions.php?lang=en

2) Permission to use maps from Google Earth - Figure 4.3

All uses of Google Maps and Google Earth Content must provide attribution to both Google and our data providers. We do not approve of any use of content without proper attribution, in any circumstance. We require attribution when the Content is shown.

https://www.google.com/permissions/geoguidelines.html https://www.google.com/permissions/geoguidelines/attr-guide.html

Map data: 2016 (c) Google Earth, Data Provider Image (c) 2016 DigitalGlobe

2010 Historical Map data: 2016 (c) Google Earth, Data Provider Image (c) 2016 DigitalGlobe 2013 Historical Map data: 2016 (c) Google Earth, Data Provider Image (c) 2016 DigitalGlobe 2002 Historical map data: 2016 (C) Google Earth Data Providers: Image (C) 2016 DigitalGlobe, Image NASA, Image Landsat/Copernicus

3) Permission to use photographs from Matthew Meglan - Figures 1.1 and 1.3

Matthew Meglan Matt@meglan.us via gmail.com

6:42 PM (13

hours ago)

to me

I Matthew Meglan give Noah Goyke full rights and privileges to use my personal photographs for academic purposes.

Signed,

Matthew Meglan

04/16/2017

4) Permission to use photographs of participants - Figures 1.1

Participant gave verbal permission for the use of their photograph. There is no reasonable way to identify the participant based on the content to the thesis. 


\section{Appendix C. Common and Scientific Names}

Table C.1. Common and Scientific Names of Medicinal Plants, organized by family.

\begin{tabular}{|c|c|c|c|}
\hline Common Name & Family & Genus & Species \\
\hline Sauco & Adoxaceae & Sambucus & australis \\
\hline Perdudilla negra & Amaranthaceae & Alternanthera & ficoidea \\
\hline Ka'are & Amaranthaceae & Chenopodium & ambrosioides \\
\hline Perdudilla blanca & Amaranthaceae & Gomphrena & celosioides \\
\hline Batatilla & Amaranthaceae & Pfaffia & glomerata \\
\hline Ajo & Amaryllidaceae & Allium & sativum \\
\hline Cebollla & Amaryllidaceae & Allium & cepa \\
\hline Yreunde & Anacardiaceae & Astronium & urundeuva \\
\hline Mango & Anacardiaceae & Mangifera & indica \\
\hline Molle'i & Anacardiaceae & Schinus & weinmannifolia \\
\hline Corazon de Hindia & Annonaceae & Annona & muricata \\
\hline Aratiku & Annonaceae & Rollinia & emarginata \\
\hline Eneldo & Apiaceae & Anethum & graveolens \\
\hline Kuratu & Apiaceae & Coriandrum & sativum \\
\hline Zanahoria & Apiaceae & Daucus & carota \\
\hline Hinojo & Apiaceae & Foeniculum & vulgare \\
\hline Perejil & Apiaceae & Petroselinum & crispum \\
\hline Anis & Apiaceae & Pimpinella & anisum \\
\hline Yerba mate & Aquifoliaceae & Ilex & paraguariensis \\
\hline Mbokaja'i & Arecaceae & Acrocomia & aculeata \\
\hline Zarzaparilla & Asparagaceae & Herreria & montevidensis \\
\hline Aloe & Asphodelaceae & Aloe & vera \\
\hline Jate'i ka'a & Asteraceae & Achyrocline & alata \\
\hline Altamisa & Asteraceae & Ambrosia & elatior \\
\hline Ajenjo & Asteraceae & Artemisia & absinthium \\
\hline Jaguarete ka'a & Asteraceae & Baccharis & trimera \\
\hline Kapi'una & Asteraceae & Bidens & pilosa \\
\hline Marcella & Asteraceae & Gnaphalium & Cheirantifolium \\
\hline Chikoria & Asteraceae & Hypochaeris & microcephala \\
\hline Jaguarete po & Asteraceae & Jungia & floribunda \\
\hline Manzanilla & Asteraceae & Matricaria & recutita \\
\hline Yerba de Lucero & Asteraceae & Pluchea & sagittalis \\
\hline Mbysauju & Asteraceae & Solidago & chilensis \\
\hline Ka'a he'e & Asteraceae & Stevia & rebaudiana \\
\hline Ovecha Ka'a & Asteraceae & Stevia & enteriensis \\
\hline Suico & Asteraceae & Tagetes & minuta \\
\hline Jaguapety & Asteraceae & Vernonia & tweediana \\
\hline Cepa Caballo & Asteraceae & Xanthium & spinosum \\
\hline
\end{tabular}




\begin{tabular}{|c|c|c|c|}
\hline Agrial & Begoniaceae & Begonia & cucullata \\
\hline Katuava & Bignoniaceae & Anemopaegma & glaucum \\
\hline Uña de Gato & Bignoniaceae & Dolichandra & ungis-cati \\
\hline Tajy pyta & Bignoniaceae & Handroanthus & impetiginosus \\
\hline Karoa & Bignoniaceae & Jacaranda & mimosifolia \\
\hline Boraja & Borginaceae & Borago & officinalis \\
\hline Colita & Borginaceae & Cordia & ecalyculata \\
\hline Peterevy & Borginaceae & Cordia & trichotoma \\
\hline Tororati & Calyceraceae & Acicarpha & tribuloides \\
\hline Jasyru & Cannabaceae & Celtis & iguanaea \\
\hline Mamon macho & Caricaceae & Carica & papaya \\
\hline Cangorosa & Celastraceae & Maytenus & ilicifolia \\
\hline Caña Brava & Costaceae & Costus & arabicus \\
\hline Esencia maravillosa & Crassulaceae & Kalanchoe & sp. \\
\hline Anda'i & Cucurbitaceae & Momordica & charantia \\
\hline Kurugua & Cucurbitaceae & Sicana & odorífera \\
\hline Kapi'i kati & Cyperaceae & Kyllinga & vaginata \\
\hline Cola del Caballo & Equisetaceae & Equisetum & giganteum \\
\hline Sangre de Drago & Euphorbiaceae & Croton & urucurana \\
\hline Aromita & Fabaceae & Acacia & aroma \\
\hline Pata de Buey & Fabaceae & Bauhinia & forficata \\
\hline Kumanda yvyra'i & Fabaceae & Cajanus & cajan \\
\hline Sen & Fabaceae & Cassia & angustifolia \\
\hline Taperyvahu & Fabaceae & Cassia & occidentalis \\
\hline Kamba aka & Fabaceae & Guibourtia & chodatiana \\
\hline Alfalfa & Fabaceae & Medicago & sativa \\
\hline Yvyra pyta & Fabaceae & Peltophorum & dubium \\
\hline Poroto & Fabaceae & Phaseolus & vulgaris \\
\hline Viñal Count & Fabaceae & Prosopis & ruscifolia \\
\hline Urusu he'e & Fabaceae & Rhynchosia & edulis \\
\hline Azafran & Iridaceae & Crocus & sativus \\
\hline Toronjil & Laminaceae & Melissa & officinalis \\
\hline Menta'i & Laminaceae & Mentha & piperita \\
\hline Yerba buena & Laminaceae & Mentha & rotundifolia \\
\hline Albahaca & Laminaceae & Ocimum & basilicum \\
\hline Oregano & Laminaceae & Origanum & vulgare \\
\hline Salvia & Laminaceae & Salvia & officinalis \\
\hline Taruma'i & Laminaceae & Vitex & cymosa \\
\hline Canela & Lauraceae & Cinnamomum & zeylanicum \\
\hline Laurel de España & Lauraceae & Laurus & nobilis \\
\hline Aguacate & Lauraceae & Persea & americana \\
\hline Lino & Linaceae & Linum & usitatissimum \\
\hline
\end{tabular}




\begin{tabular}{|c|c|c|c|}
\hline Siete Sangria & Lythraceae & Cuphea & racemosa \\
\hline Ysupopere & Lythraceae & Cuphea & Iysimachioides \\
\hline Yerba de Vida & Lythraceae & Heimia & salicifolia \\
\hline Granada & Lythraceae & Punica & granatum \\
\hline Suerola & Malpighiaceae & Malpighia & emarginata \\
\hline Malva blanca & Malvaceae & Sida & cordifolia \\
\hline Tillo & Malvaceae & Tilia & x europea \\
\hline Boldo & Monimiaceae & Peumus & boldus \\
\hline Tarope & Moraceae & Dorstenia & brasiliensis \\
\hline Tatajyva & Moraceae & Maclura & tinctoria \\
\hline Mora & Moraceae & Morus & alba \\
\hline Ñandupa & Moraceae & Sorocea & bonplandii \\
\hline Moringa & Moringaceae & Moringa & Oleifera \\
\hline Guarivami & Myrtaceae & Campomanesia & adenantium \\
\hline Eucalypto & Myrtaceae & Eucalyptus & citriodora \\
\hline Ñanga piru & Myrtaceae & Eugenia & uniflora \\
\hline Arasa & Myrtaceae & Psidium & guajava \\
\hline Ka'a rurupe & Nyctaginaceae & Boerhavia & diffusa \\
\hline Mburucuja & Passifloraceae & Passiflora & caerulea \\
\hline Pipi & Petiveriaceae & Petiveria & alliacea \\
\hline Para para'i & Phyllanthaceae & Phyllanthus & orbiculatus \\
\hline Jatevu ka'a & Piperaceae & Peperomia & spp. \\
\hline Jaguarundi & Piperaceae & Piper & regnellii \\
\hline Llantem & Plantaginaceae & Plantago & spp \\
\hline Cedron Kapi'i & Poaceae & Cymbopogon & citratus \\
\hline Sevada & Poaceae & Hordeum & vulgare \\
\hline Kapi'i pepoha & Poaceae & Paspalum & distichum \\
\hline Alpiste & Poaceae & Phalaris & canariensis \\
\hline Ruivargo & Polygonaceae & Rheum & rhabarbarum \\
\hline Calaval'i & Polypodiaceae & Campyloneurum & phyllitidis \\
\hline Dordilla & Pteridaceae & Adiantopsis & chlorophylla \\
\hline Cabello de Angel & Ranunculaceae & Clematis & campestris \\
\hline Nispero & Rosaceae & Eriobotrya & japonica \\
\hline Frutilla & Rosaceae & Fragaria & $\mathrm{x}$ ananassa \\
\hline Ciduela & Rosaceae & Prunus & domestica \\
\hline Rosa moroti & Rosaceae & Rosa & banksiae \\
\hline Tupucha Coredor & Rubiaceae & Borreria & verticillata \\
\hline Limon sutil & Rutaceae & Citrus & $x$ aurantifolia \\
\hline Mandarina & Rutaceae & Citrus & reticulata \\
\hline Naranja hái & Rutaceae & Citrus & $\mathrm{x}$ aurantium \\
\hline Pomelo & Rutaceae & Citrus & paradisi \\
\hline Ruda & Rutaceae & Ruta & graveolens \\
\hline
\end{tabular}




\begin{tabular}{llll}
\hline Tembetary & Rutaceae & Zanthoxylum & rhoifolium \\
\hline Koku & Sapindaceae & Allophylus & edulis \\
\hline Yva po'o & Sapindaceae & Melicoccus & lepidopetalus \\
\hline Chiquita & Sapotaceae & Chrysophyllum & marginatum \\
\hline Tupasy Kamby & Scrophulariaceae & Scoparia & dulcis \\
\hline Kamambu'i & Solanaceae & Physalis & viscosa \\
\hline Jurea & Solanaceae & Solanum & paniculatum \\
\hline Ñuatî pytã & Solanaceae & Solanum & sisybriifolium \\
\hline Papa & Solanaceae & Solanum & tuberosum \\
\hline Amba'y & Urticaceae & Cecropia & pachystachya \\
\hline Pyno guasu & Urticaceae & Urera & baccifera \\
\hline Ortiga & Urticaceae & urtica & dioica \\
\hline Pyno'i & Urticaceae & Urtica & spathulata \\
\hline Burrito & Verbenaceae & Aloysia & polystachya \\
\hline Cedron Paraguay & Verbenaceae & Aloysia & citriodora \\
\hline Poleo'i & Verbenaceae & Aloysia & gratissima \\
\hline Margarita pyta & Verbenaceae & Glandularia & peruviana \\
\hline Taturygui & Verbenaceae & Stachytarpheta & cayennensis \\
\hline Vervena'i & Verbenaceae & Verbena & bonariensis \\
\hline Palo Santo & Zygophyllaceae & Bulnesia & sarmientoi \\
\hline Guajakan & Zygophyllaceae & Guaiacum & Officinale \\
\hline
\end{tabular}

